\title{
8. COMPARISON OF UPPER PLIOCENE DISCOASTER ABUNDANCE VARIATIONS FROM NORTH ATLANTIC SITES 552, 607, 658, 659, AND 662: FURTHER EVIDENCE FOR MARINE PLANKTON RESPONDING TO ORBITAL FORCING ${ }^{1}$
}

\author{
Alex Chepstow-Lusty, ${ }^{2}$ Jan Backman, ${ }^{3}$ and Nicholas J. Shackleton ${ }^{2}$
}

\begin{abstract}
Abundance variations of six Pliocene species of discoasters have been analyzed over the time interval from 1.89 to $2.95 \mathrm{Ma}$ at five contrasting sites in the North Atlantic: Deep Sea Drilling Project Sites $552\left(56^{\circ} \mathrm{N}\right)$ and $607\left(41^{\circ} \mathrm{N}\right)$ and Ocean Drilling Program $658\left(20^{\circ} \mathrm{N}\right), 659\left(18^{\circ} \mathrm{N}\right)$, and $662\left(1^{\circ} \mathrm{S}\right)$. A sampling interval equivalent to approximately $3 \mathrm{k} . y$. was used. Total Discoaster abundance showed a reduction with increasing latitude and from the effects of upwelling.

This phenomenon is most obvious in Discoaster brouweri, the only species that survived over the entire time interval studied. Prior to $2.38 \mathrm{Ma}$, Discoaster pentaradiatus and Discoaster surculus are important components of the Discoaster assemblage: Discoaster pentaradiatus increases slightly with latitude up to $41^{\circ} \mathrm{N}$, and its abundance relative to $D$. brouweri increases up to $56^{\circ} \mathrm{N} ; D$. surculus increases in abundance with latitude and with upwelling conditions relative to both $D$. brouweri and $D$. pentaradiatus and is dominant to the latter species at upwelling Site 658 and at the highest latitude sites. Discoaster asymmetricus and Discoaster tamalis appear to increase in abundance with latitude relative to $D$. brouweri.

Many of the abundance changes observed appear to be connected with the initiation of glaciation in the North Atlantic at 2.4 Ma. The long-term trend of decreasing Discoaster abundance probably reflects the fall of sea-surface temperatures. This trend of cooling is overprinted by short-term variations that are probably associated with orbital forcing. Evidence for the astronomical elements of eccentricity and obliquity periodicities were found at all sites; however, only at Sites 607,659 , and 662 were precessional periodicities detected. Furthermore, only at Site 659 was precession found to be dominant to obliquity.

Abundance peaks of individual species were found to cross-correlate between sites. The distinct abundance fluctuations observed especially in the tropics suggest that temperature is not the only factor responsible for this variation. This study reveals for the first time the importance of productivity pressure on the suppression of Discoaster abundance.
\end{abstract}

\section{INTRODUCTION}

Discoasters are known in the oceanic record from the upper Paleocene to the upper Pliocene, when the last two representatives of the genus disappeared synchronously just below the base of the Olduvai Subchron, 1.89 Ma ago (Takayama, 1970; Rio, 1982; Backman and Shackleton, 1983). Numerous studies have shown that discoasters are particularly common in low-latitude sediments and therefore probably favored warm-water masses (e.g., Haq and Lohmann, 1976; Bukry, 1978). The organism from which discoasters evolved is not known, but it was presumably related to the coccolithophorids. Discoasters are favorable for quantitative study since they resist dissolution better than planktonic foraminifers or most placoliths (Lohmann and Carlson, 1981).

A number of factors probably affected their distribution, but this genus appears especially sensitive to temperature change (Haq and Lohmann, 1976). Backman et al. (1986) and Backman and Pestiaux (1987) have shown that orbital forcing is strongly imprinted on Discoaster abundance variation at Deep Sea Drilling Project (DSDP) Hole $552 \mathrm{~A}\left(56^{\circ} \mathrm{N}\right)$ and DSDP Site $606\left(37^{\circ} \mathrm{N}\right)$ during the Pliocene in the North Atlantic. The former is dominated by the 41-k.y. obliquity periodicity and the latter by the $400-k . y$. eccentricity periodicity.

\footnotetext{
${ }^{1}$ Ruddiman, W., Sarnthein, M., et al., 1989. Proc. ODP, Sci. Results, 108: College Station, TX (Ocean Drilling Program).

2 Godwin Laboratory, Subdepartment of Quaternary Research, University of Cambridge, Cambridge CB2 3RS, United Kingdom.

3 Department of Geology, University of Stockholm, S-10691 Stockholm,
}

In the present study, individual species and total abundances of discoasters are compared among five sites across a wide latitudinal range of the North Atlantic. We hope to extend this research approach to other oceans and develop a global data base. As more sites are analyzed and compared, Discoaster abundance variations may give us a global record of ocean temperature changes and/or nutrient levels.

In addition, after we obtain continuous quantitative estimates of Discoaster abundances, we will also be able to use spectral analysis to determine whether orbital forcing is imprinted on the Discoaster record at these sites. The time interval investigated is approximately the million years preceding the extinction of the discoasters (i.e., between 1.9 and $2.9 \mathrm{Ma}$ ) using closely spaced samples (around 3 k.y.). The taxonomy of the six species of discoasters counted (Plate 1) and the methods used in this study follow those of Backman and Shackleton (1983).

\section{SITES SELECTED}

The five sites chosen (Fig. 1 and Table 1) were picked to contrast with each other either in terms of latitude, upwelling vs. nonupwelling systems, and the effects of cool currents. However, all sites are from the eastern North Atlantic, which may limit our interpretations. The sites possess good sequences of upper Pliocene sediment and, except for Hole $552 \mathrm{~A}$, fairly high sedimentation rates. Sampling was at $10-\mathrm{cm}$ intervals except for Sites 607 and 658 , which were at $15-\mathrm{cm}$ and $30-\mathrm{cm}$ intervals, respectively.

\section{Site 659}

This site was selected as the nonupwelling, open-ocean reference site. It is located on the top of the Cape Verde 


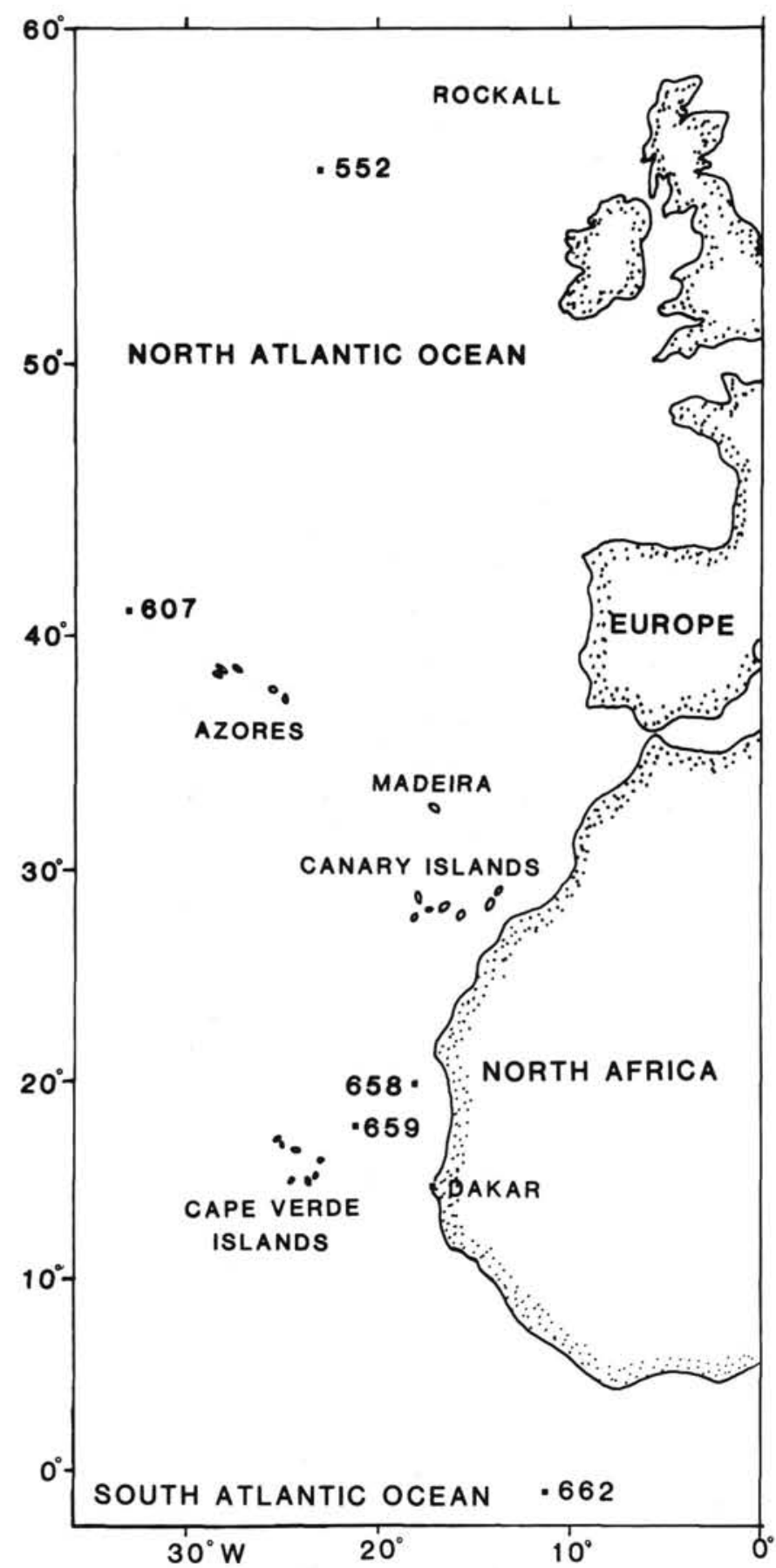

Figure 1. Location of sites studied in the North Atlantic.

Plateau. The oceanographic setting is not complicated by the cool Canaries Current or by large inputs of terrigenous matter from northwest Africa. The lithology is mostly nannofossilforaminifer ooze with good preservation and no noticeable dissolution in the interval studied.

\section{Site 658}

In contrast, Site 658 was the upwelling, high-productivity site chosen in close proximity to Site 659 . It is located on the continental slope $160 \mathrm{~km}$ west of Cap Blanc and lies beneath a major productive cell of oceanic upwelling. The sediments are hemipelagic due to the combined influence of oceanic
Table 1. North Atlantic sites selected, their geographic positions, and water depth.

\begin{tabular}{lccl}
\hline Hole & Location & $\begin{array}{c}\text { Depth } \\
(\mathrm{m})\end{array}$ & \multicolumn{1}{c}{ Reference } \\
\hline $662 \mathrm{~A}$ & $1^{\circ} \mathrm{S}, 11^{\circ} \mathrm{W}$ & 3,824 & Ruddiman, Sarnthein, et al., 1988 \\
$659 \mathrm{~A}$ & $18^{\circ} \mathrm{N}, 21^{\circ} \mathrm{W}$ & 3,067 & Ruddiman, Sarnthein, et al., 1988 \\
$658 \mathrm{~A}$ & $20^{\circ} \mathrm{N}, 18^{\circ} \mathrm{W}$ & 2,263 & Ruddiman, Sarnthein, et al., 1988 \\
607 & $41^{\circ} \mathrm{N}, 33^{\circ} \mathrm{W}$ & 3,427 & Ruddiman, Kidd, Thomas, et al., 1987 \\
$552 \mathrm{~A}$ & $56^{\circ} \mathrm{N}, 23^{\circ} \mathrm{W}$ & 2,304 & Roberts, Schnitker, et al., 1984 \\
\hline
\end{tabular}

production and eolian input. Discoasters may have fluctuated in response to the intensity of upwelling.

\section{Site 662}

This site is located close to the equator on the upper eastern flank of the mid-Atlantic Ridge. The relevant interval is a nannofossil and foraminifer-nannofossil ooze. One would expect discoasters to be extremely abundant in such low latitudes, although this site is influenced by the South Equatorial Current, which is the successor to the Benguela Current. It is within the equatorial divergence and may be affected by upwelling.

\section{Site 607}

This site is presently located along the northernmost part of the subtropical gyre; however, in the late Pliocene, it was exposed to major circulation changes and lower temperatures (Ruddiman, Sarnthein, et al., 1988). The lithology is interbedded foraminifer-nannofossil oozes and marls representing the North Atlantic glacial marine cycles.

\section{Site 552}

This site is at the northernmost latitude of our transect. The data for this site was published by Backman and Pestiaux (1987) and has been replotted to provide a comparison with the other sites. It was drilled on the southwest margin of the Rockall Plateau and the lithology is similar to Site 607 in that it consists of cycles of alternating beds of foraminifer-nannofossil ooze and calcareous marls and mud that began abruptly about 2.4 Ma. Prior to this age, the lithology is relatively uniform foraminifer-nannofossil ooze and nannofossil ooze.

\section{AGE MODELS AND SEDIMENTATION RATES}

In the absence of magnetostratigraphic data from Sites 659 and 662 and imprecise data from Site 658, all age models are based on biostratigraphic datums. However, at Sites 552 and 607 very reliable magnetic stratigraphies were obtained. Only three stratigraphic datums have been selected as control points for the age models at each site. Where it was possible, biostratigraphic datums were selected preferentially, especially those related to Discoaster events (Table 2). This ensures that the age models from the five sites are selfconsistent.

At Site 659 magnetic data was available for most of Hole $659 \mathrm{~B}$, but magnetic reversals were unambiguous only in the upper section of Hole $659 \mathrm{~A}$. Using distinct $D$. brouweri abundance peaks for correlation, it was possible to switch from Hole $659 \mathrm{~A}$ to Hole $659 \mathrm{~B}$ to obtain the extinction event, which was not recovered in Hole 659A. Most of the species events fit a single line on the age-depth plot (Fig. 2). To develop the age model, we used the datums of the extinction of $D$. brouweri and $D$. triradiatus at $1.89 \mathrm{Ma}$, the base of the D. triradiatus acme at $2.07 \mathrm{Ma}$ (Backman and Shackleton, 1983), and the extinction of D. tamalis at 2.65 Ma (Table 3 ). 
Table 2. Summary of Discoaster events between 1.89 and $3.00 \mathrm{Ma}$ from previous work (e.g., Backman and Shackleton, 1983; Backman et al., 1986).

\begin{tabular}{lcl}
\hline \multicolumn{1}{c}{ Species } & $\begin{array}{c}\text { Age } \\
\text { (Ma) }\end{array}$ & \multicolumn{1}{c}{ Event } \\
\hline D. brouweri & 1.89 & Extinction \\
D. triradiatus & 1.89 & Extinction \\
D. triradiatus & 2.07 & Peak abundance began \\
D. pentaradiatus & $2.33-2.43$ & Extinction \\
D. surculus & $2.42-2.46$ & Extinction \\
D. surculus & 2.39 & axtinction \\
D. asymmetricus & 2.65 & Abundance decline \\
D. tamalis & 2.65 & Extinction \\
D. variabilis & $2.87-2.93$ & Extinction \\
\hline
\end{tabular}

${ }^{\text {a }}$ Estimate for extinction from this study.

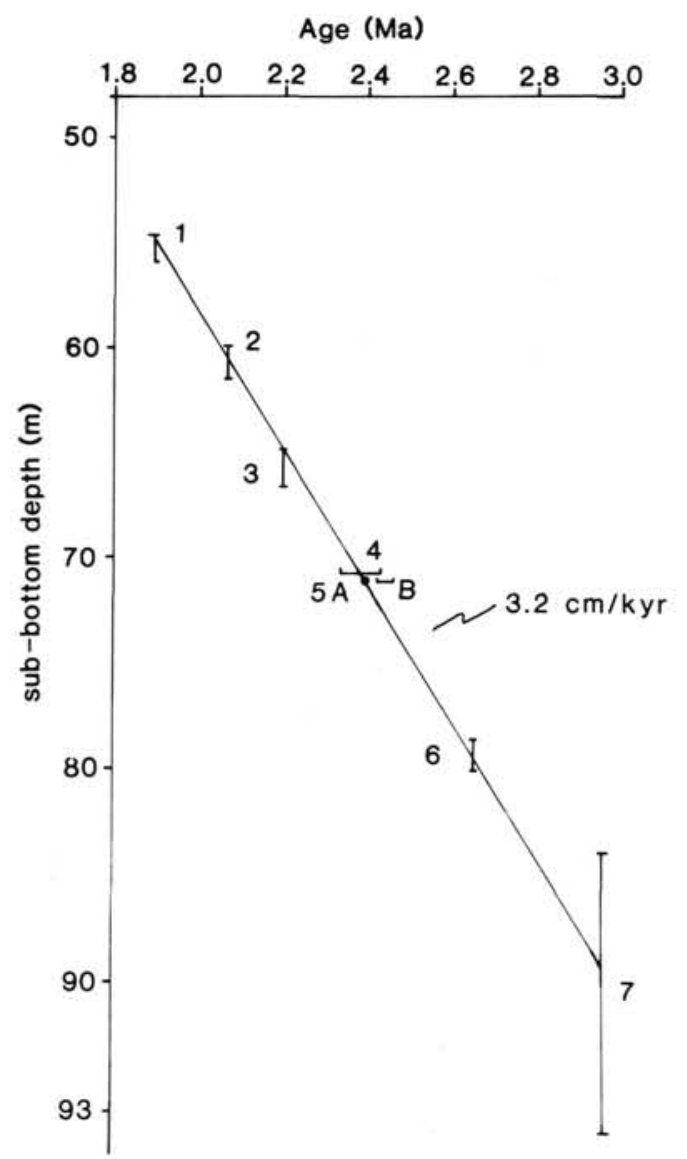

Figure 2. Age/depth relationships of biochronologic control points in Hole 659A. Refer to Table 4 for control points used.

Site 659 may provide new information about the extinction of D. surculus. Backman and Shackleton (1983) originally determined the extinction of $D$. surculus from several piston cores having magnetostratigraphy. Core V32-127 (North Pacific) provided an unambiguous final sharp decline in the abundance of $D$. surculus, and the age of this event was estimated to range from 2.38 to $2.44 \mathrm{Ma}$ in this core. Subsequently, Backman and Pestiaux (1987) derived an age range from 2.42 to $2.46 \mathrm{Ma}$ for the $D$. surculus extinction event, based on a less clear final abundance pattern obtained from DSDP Hole 606 (North Atlantic). Thus, the question if this species experienced a synchronous extinction in different ocean basins (or latitudes) will remain open until additional
Table 3. Summary of control points used in age models.

\begin{tabular}{|c|c|c|c|c|}
\hline Datum & $\begin{array}{l}\text { Age } \\
(\mathrm{Ma})\end{array}$ & $\begin{array}{l}\text { Depth } \\
\text { (mbsf) }\end{array}$ & Event & $\begin{array}{l}\text { Sedimentation } \\
\text { rate }\end{array}$ \\
\hline $\begin{array}{l}\text { Hole } 659 \mathrm{~A}: \\
\text { D. brouweri } \\
\text { D. triradiatus } \\
\text { D. tamalis }\end{array}$ & $\begin{array}{l}1.89 \\
2.07 \\
2.65\end{array}$ & $\begin{array}{l}54.8 \\
60.6 \\
79.4\end{array}$ & $\begin{array}{l}\text { Extinction } \\
\text { Peak abundance began } \\
\text { Extinction }\end{array}$ & $\begin{array}{l}3.2 \mathrm{~cm} / \mathrm{k} . \mathrm{y} \\
3.2 \mathrm{~cm} / \mathrm{k} . \mathrm{y}\end{array}$ \\
\hline $\begin{array}{l}\text { Hole } 658 \mathrm{~A}: \\
\text { D. brouweri } \\
\text { D. surculus } \\
\text { D. altispira }\end{array}$ & $\begin{array}{l}1.89 \\
2.39 \\
2.95\end{array}$ & $\begin{array}{r}26.4 \\
166.0 \\
\mathrm{a}_{22} 20.0\end{array}$ & $\begin{array}{l}\text { Extinction } \\
\text { Extinction } \\
\text { Extinction }\end{array}$ & $\begin{array}{l}7.9 \mathrm{~cm} / \mathrm{k} . \mathrm{y} \\
9.6 \mathrm{~cm} / \mathrm{k} . \mathrm{y}\end{array}$ \\
\hline $\begin{array}{l}\text { Hole } 662 \mathrm{~A}: \\
\text { D. brouweri } \\
\text { D. surculus } \\
\text { G. altispira }\end{array}$ & $\begin{array}{l}1.89 \\
2.39 \\
2.95\end{array}$ & $\begin{array}{r}123.2 \\
151.4 \\
\mathrm{a}_{168.5}\end{array}$ & $\begin{array}{l}\text { Extinction } \\
\text { Extinction } \\
\text { Extinction }\end{array}$ & $\begin{array}{l}5.6 \mathrm{~cm} / \mathrm{k} . \mathrm{y} \\
3.1 \mathrm{~cm} / \mathrm{k} . \mathrm{y}\end{array}$ \\
\hline $\begin{array}{l}\text { Hole } 607 \mathrm{~A} \text { : } \\
\text { D. brouweri } \\
\text { D. surculus } \\
\text { Kaena }\end{array}$ & $\begin{array}{l}1.89 \\
2.39 \\
2.99\end{array}$ & $\begin{array}{r}82.86 \\
106.78 \\
130.73\end{array}$ & $\begin{array}{l}\text { Extinction } \\
\text { Extinction } \\
\text { Bottom }\end{array}$ & $\begin{array}{l}4.8 \mathrm{~cm} / \mathrm{k} . \mathrm{y} \\
4.0 \mathrm{~cm} / \mathrm{k} . \mathrm{y}\end{array}$ \\
\hline $\begin{array}{l}\text { Hole } 552 \mathrm{~A}: \\
\text { D. brouweri } \\
\text { D. surculus } \\
\text { Kaena }\end{array}$ & $\begin{array}{l}1.89 \\
2.39 \\
2.99\end{array}$ & $\begin{array}{l}35.2 \\
42.5 \\
48.6\end{array}$ & $\begin{array}{l}\text { Extinction } \\
\text { Extinction } \\
\text { Bottom }\end{array}$ & $\begin{array}{l}1.4 \mathrm{~cm} / \mathrm{k} . \mathrm{y} \\
1.0 \mathrm{~cm} / \mathrm{k} . \mathrm{y}\end{array}$ \\
\hline
\end{tabular}

${ }^{a}$ Refers to P. Weaver (this vol.).

Table 4. Datum levels used to construct Figure 2.

\begin{tabular}{llcc}
\hline Number & \multicolumn{1}{c}{ Datum level } & $\begin{array}{c}\text { Depth } \\
(\mathrm{mbsf})\end{array}$ & $\begin{array}{c}\text { Age } \\
(\mathrm{Ma})\end{array}$ \\
\hline $\begin{array}{l}\text { Hole 659A: } \\
1\end{array}$ & LAD D. brouweri & $54.7-55.9$ & 1.89 \\
2 & Base of D. triradiatus & $59.8-61.3$ & 2.07 \\
& acme & & \\
3 & LAD G. miocenica & $64.8-65.6$ & 2.20 \\
4 & LAD D. pentaradiatus & 70.7 & $2.33-2.43$ \\
$5 \mathrm{~A}$ & New LAD D. surculus & 71.0 & 2.39 \\
$5 \mathrm{~B}$ & LAD D. surculus & 71.0 & $\mathrm{~b}_{2} 2.42-2.45$ \\
6 & LAD D. tamalis & $78.5-80.0$ & 2.65 \\
7 & LAD G. altispira & $83.8-93.8$ & 2.95 \\
\hline
\end{tabular}

${ }^{a}$ Estimated from Figure 2.

b Backman and Shackleton, 1983.

independent evidence (e.g., highly resolved stable isotope stratigraphy) can be used for precise calibration. Currently, the uncertainty is about $80 \mathrm{k}$.y. between 2.38 and $2.46 \mathrm{Ma}$.

The three Leg 108 sites analyzed in this study reveal rather similar patterns of abundance variation of $D$. surculus, particularly toward the end of its range, finishing with a final sharp peak that is assumed to be synchronous. The Pliocene/Pleistocene sedimentation rate at Site 659 appears remarkably constant (Ruddiman, Sarnthein, et al., 1988), fitting all available biostratigraphic datum events, from the last appearance datum (LAD) of D. brouweri at $1.89 \mathrm{Ma}$ to the LAD of Globorotalia altispira at $2.95 \mathrm{Ma}$ (Fig. 2 and Table 4). Only the LAD of $D$. surculus falls slightly off the line if the age estimates from DSDP Site 606 are used. As a working hypothesis, the age estimate of $D$. surculus is adjusted in order to fit the apparently linear sedimentation rate at Site 659. This gives a value of $2.39 \mathrm{Ma}$ for the final peak, which is within the range of the estimates derived from Core V32-127. This value of 2.39 Ma was applied thereafter to all other investigated sites in order to produce consistent age models.

At Site 658, magnetostratigraphic data was available for the interval representing the base of the Olduvai, but the Matuya$\mathrm{ma} / \mathrm{Gauss}$ boundary data was too scattered to be reliable. To be internally consistent, only biostratigraphic datums have 


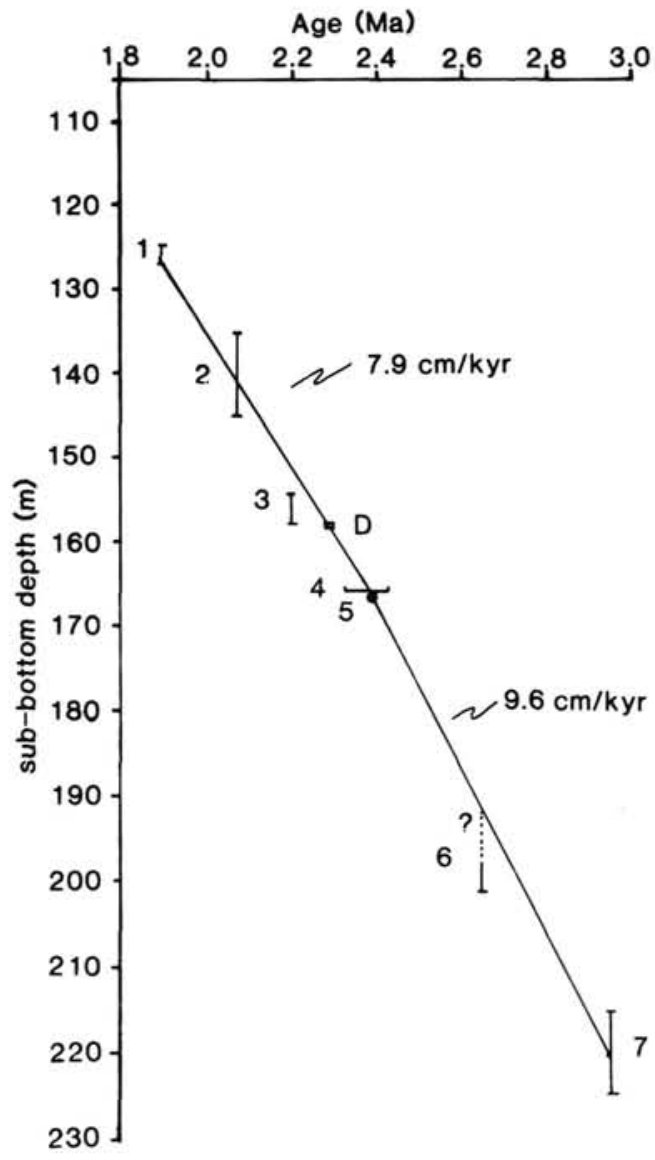

Figure 3. Age/depth relationships of biochronologic and magnetostratigraphic control points in Hole 658A. Refer to Table 5 for control points used.

Table 5. Datum levels used to construct Figure 3.

\begin{tabular}{clcc}
\hline Number & \multicolumn{1}{c}{ Datum level } & $\begin{array}{c}\text { Depth } \\
\text { (mbsf) }\end{array}$ & $\begin{array}{c}\text { Age } \\
(\mathrm{Ma})\end{array}$ \\
\hline $\begin{array}{c}\text { Hole 658A: } \\
1\end{array}$ & LAD D. brouweri & $124.7-126.9$ & 1.89 \\
2 & Base of D. triradiatus & $135.0-145.0$ & 2.07 \\
& acme & $154.3-157.7$ & 2.20 \\
3 & LAD G. miocenica & 165.5 & $2.33-2.43$ \\
4 & LAD D. pentaradiatus & 166.0 & 2.39 \\
a & LAD D. surculus & $197.7-201.3$ & 2.65 \\
6 & LAD D. tamalis & $214.9-224.4$ & 2.95 \\
7 & LAD G. altispira & $157.8-158.4$ & $\mathrm{~b}_{2.30}$ \\
D & Diagenetic event & & \\
\hline
\end{tabular}

${ }^{\text {a }}$ LAD for D. surculus taken as 2.39 Ma from Site 659 (Table 4).

b Inferred from Figure 3.

been used in the construction of the age-depth plot at Site 658 (Fig. 3 and Table 5). Discoaster brouweri provided a clear extinction, but the base of the $D$. triradiatus acme has a fairly wide estimate that is probably due to the low numbers of these two species. A line was drawn through the extinction of $D$. brouweri to the extinction of $D$. surculus, passing through the range of estimates for the base of the $D$. triradiatus acme and the extinction of $D$. pentaradiatus.

For the rest of the age-depth plot for Site 658 , a line was drawn from the extinction of $D$. surculus through the extinction of Globorotalia altispira at $2.95 \mathrm{Ma}$ (Ruddiman, Sarnthein, et al., 1988). Discoaster tamalis was not useful in the age-depth plot

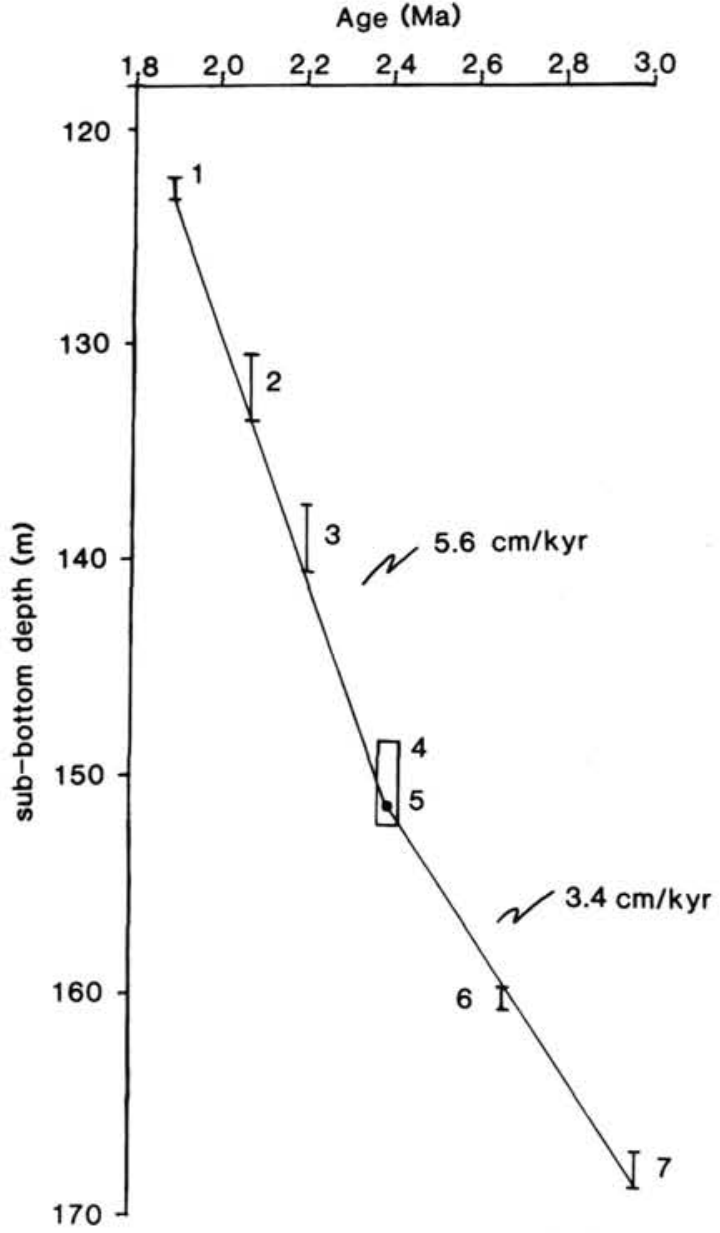

Figure 4. Age/depth relationships of biochronologic control points in Hole 662 A. Refer to Table 6 for control points used.

Table 6. Datum levels used to construct Figure 4.

\begin{tabular}{clcc}
\hline Number & \multicolumn{1}{c}{ Datum level } & $\begin{array}{c}\text { Depth } \\
(\mathrm{mbsf})\end{array}$ & $\begin{array}{c}\text { Age } \\
(\mathrm{Ma})\end{array}$ \\
\hline $\begin{array}{c}\text { Hole 662A: } \\
1\end{array}$ & LAD D. brouweri & $122.2-123.2$ & 1.89 \\
2 & Base of D. triradiatus & $130.4-133.5$ & 2.07 \\
& acme & $137.5-140.5$ & 2.20 \\
3 & LAD G. miocenica & $148.3-152.1$ & $2.33-2.43$ \\
4 & LAD D. pentaradiatus & 151.4 & 2.39 \\
$a_{5}$ & LAD D. surculus & $159.5-160.5$ & 2.65 \\
6 & LAD D. tamalis & $166.9-168.5$ & 2.95 \\
7 & LAD G. altispira & & \\
\hline
\end{tabular}

${ }^{\text {a }}$ LAD for D. surculus taken as $2.39 \mathrm{Ma}$ from Site 659 (Table 4).

since it occurred in numbers too low to provide a reliable datum. Thus, we used the extinction datums of $D$. brouweri, $D$. surculus, and G. altispira in our age model (Table 3).

An interesting diagenetic event, the formation of a possible "hardground" occurring between 157.8 and 158.4 mbsf, is associated with some reworking of $D$. pentaradiatus and $D$. surculus. This event necessitated a change of drilling from hydraulic piston corer (HPC) to extended core barrel (XCB). From the age model this occurred at approximately $2.3 \mathrm{Ma}$.

At Site 662 (Fig. 4 and Table 6), there was no magnetic stratigraphy available, and reworking was noticeably greater than at Sites 658 and 659 . This site was affected by slumping, but this was above the interval studied. Due to the reworking, some 


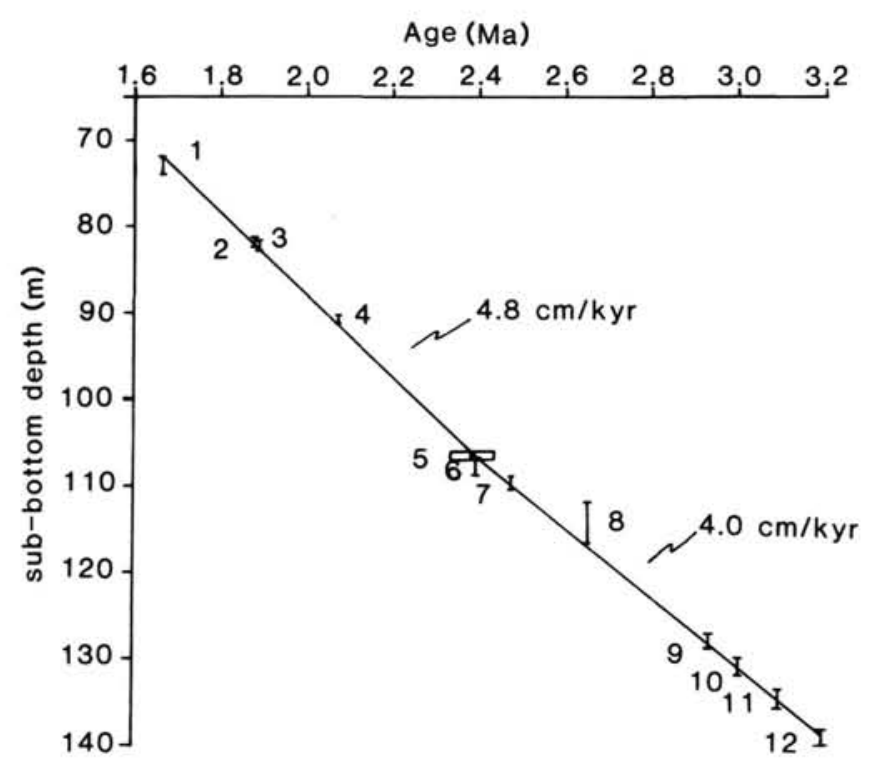

Figure 5. Age/depth relationships of biochronologic and magnetostratigraphic control points in Hole 607A. Refer to Table 7 for control points used.

Table 7. Datum levels used to construct Figure 5.

\begin{tabular}{rlcc}
\hline Number & \multicolumn{1}{c}{ Datum level } & $\begin{array}{c}\text { Depth } \\
(\mathrm{mbsf})\end{array}$ & $\begin{array}{c}\text { Age } \\
(\mathrm{Ma})\end{array}$ \\
\hline 1 & Olduvai (Top) & $72.08-74.18$ & 1.66 \\
2 & Olduvai (Bottom) & $81.68-82.46$ & 1.88 \\
3 & LAD D. brouweri & $81.80-83.10$ & 1.89 \\
4 & Base of D. triradiatus & $90.60-91.48$ & 2.07 \\
& acme & $106.35-107.38$ & $2.33-2.43$ \\
5 & LAD D. pentaradiatus & $106.78-108.52$ & 2.39 \\
76 & LAD D. surculus & $108.98-110.57$ & 2.47 \\
7 & Matuyama/Gauss boundary & $111.90-116.68$ & 2.65 \\
8 & LAD D. tamalis & $126.68-128.18$ & 2.92 \\
9 & Kaena (Top) & $129.68-131.78$ & 2.99 \\
10 & Kaena (Bottom) & $133.28-135.05$ & 3.08 \\
11 & Mammoth (Top) & $137.78-139.28$ & 3.18 \\
12 & Mammoth (Bottom) & & \\
\hline
\end{tabular}

${ }^{\text {a }}$ LAD for D. surculus taken as 2.39 Ma from Site 659 (Table 4).

events such as the base of the D. triradiatus acme were difficult to identify precisely. Discoaster pentaradiatus was heavily reworked through the interval, and it is important to have some concept of the background reworking level when defining extinction events. Discoaster surculus again produced a distinct peak at its extinction. Likewise, D. tamalis produced a clear extinction at $2.65 \mathrm{Ma}$. From the age-depth plot, the extinction of $D$. brouweri, D. surculus, and G. altispira were selected as datums to be used in the age model (Table 3 ).

At Site 607 , a very reliable magnetic stratigraphy was obtained (Fig. 5 and Table 7) (Clement and Robinson, 1987). A straight line connects the top of the Olduvai with the extinction of D. surculus at $2.39 \mathrm{Ma}$, passing through the base of the Olduvai, the extinction of $D$. brouweri, the base of the acme of $D$. triradiatus, and the extinction of $D$. pentaradiatus. Prior to $2.39 \mathrm{Ma}$, there is a slightly lower sedimentation rate, but a straight line can be drawn between the extinction of $D$. surculus and the bottom of the Mammoth (3.18 Ma), passing through the Matuyama/Gauss boundary, the top and bottom of the Kaena, and the top of the Mammoth. Discoaster tamalis was not useful since the extinction was disguised by reworking, clearly indicated by the presence of Reticu-

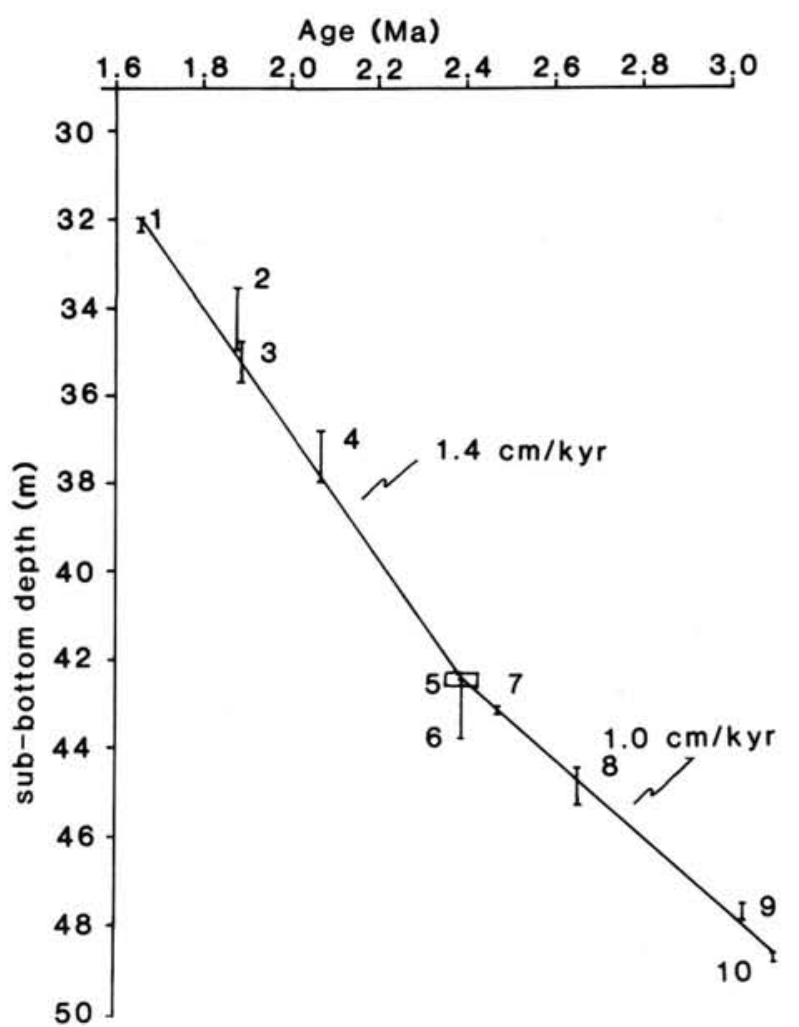

Figure 6. Age/depth relationships of biochronologic and magnetostratigraphic control points in Hole 552A. Refer to Table 8 for control points used.

Table 8. Datum levels used to construct Figure 6.

\begin{tabular}{clcc}
\hline Number & \multicolumn{1}{c}{ Datum level } & $\begin{array}{c}\text { Depth } \\
(\mathrm{mbsf})\end{array}$ & $\begin{array}{c}\text { Age } \\
(\mathrm{Ma})\end{array}$ \\
\hline $\begin{array}{clcc}\text { Hole 552A: } \\
1\end{array}$ & Olduvai (Top) & $31.96-32.24$ & 1.66 \\
2 & Olduvai (Bottom) & $33.53-34.96$ & 1.88 \\
3 & LAD D. brouweri & $34.80-35.69$ & 1.89 \\
4 & Base of D. triradiatus & $36.79-38.00$ & 2.07 \\
& acme & & \\
5 & LAD D. pentaradiatus & $42.20-42.60$ & $2.33-2.43$ \\
${ }^{2} 6$ & LAD D. surculus & $42.40-43.80$ & 2.39 \\
7 & Matuyama/Gauss boundary & $43.04-43.24$ & 2.47 \\
8 & LAD D. tamalis & $44.50-45.30$ & 2.65 \\
9 & Kaena (Top) & $47.53-47.86$ & 2.92 \\
10 & Kaena (Bottom) & $47.58-48.75$ & 2.99 \\
\hline
\end{tabular}

${ }^{\text {a }}$ LAD for $D$. surculus taken as 2.39 Ma from Site 659 (Table 4).

lofenestra pseudoumbilica $(\mathrm{LAD}=3.56 \mathrm{Ma})$. From the agedepth plot, we selected the LAD of $D$. brouweri and $D$. surculus and the midpoint of the base of the Kaena at $2.99 \mathrm{Ma}$ as control points for the age model (Table 3).

At Site 552, reliable magnetic stratigraphy was available and helped verify that, in spite of the extremely low abundances of discoasters at high latitudes, the events recognized were genuine and not an artifact of reworking (Fig. 6 and Table 8). A straight line connects the top of the Olduvai and the extinction of $D$. surculus $(2.39 \mathrm{Ma})$, passing through the extinction of $D$. brouweri (and close to the base of the Olduvai), the base of the $D$. triradiatus acme, and the extinction of $D$. pentaradiatus. Prior to $2.39 \mathrm{Ma}$, there is a slight reduction in the sedimentation rate, but a straight line can be drawn through the Matuyama/Gauss boundary, the extinction 
of D. tamalis, and the bottom of the Kaena, passing close to the top of the Kaena. From the age-depth plot, we selected the LAD of $D$. brouweri and D. surculus and the bottom of the Kaena as control points for the age model (Table 3). Sedimentation rates at this site were much lower than at any of the other sites.

\section{COMPARISON OF SPECIES AND TOTAL ABUNDANCE AMONG SITES}

Smear slides were prepared and counted as described by Backman and Shackleton (1983). The number of view fields selected is related to the overall abundance of discoasters at each site. Normally, a constant number of view fields are used for a single site, except possibly during intervals of extremely low abundances. Abundances among sites were directly comparable when they were multiplied by a conversion factor, which yielded the abundances per $\mathrm{mm}^{2}$ of slide.

At Site 659 , it was necessary to count only 20 view fields in view of the high Discoaster abundances. This is at a view-field diameter of $0.3 \mathrm{~mm}$, which contains roughly 250 nannofossils or other particles in each view field. However, at Site 658, where the abundances observed were found to be much lower, 40 view fields were counted. Similarly, at Site 662, 40 view fields were used. However, at Site 552, where low abundances were observed due to the high latitude, 100 view fields were used. Lastly, at Site 607, the second highest latitude site, 30 view fields were counted at a view field diameter of $0.28 \mathrm{~mm}$, as a different microscope used for this site. We found that this method is an accurate tool for gathering reproducible data rapidly.

\section{Discoaster brouweri and Discoaster triradiatus}

These two species have extinctions at $1.89 \mathrm{Ma}$. An interesting phenomenon occurs globally at $2.07 \mathrm{Ma}$ (Backman and Shackleton, 1983) when $D$. triradiatus increases in proportion $(>20 \%$ ) relative to $D$. brouweri, whereas prior to $2.07 \mathrm{Ma}$ it is insignificant. At Sites 607 and 659 (Figs. 7 and 8), this event was clearly defined; but at Sites 658 and 552 (Figs. 9 and 10) and to a lesser extent at Site 662 (Fig. 11), it was less easy to identify precisely. Extremely low abundances of the two species occur at Site 658 , and the base of the acme probably lies between 138.7 and 141.5 mbsf (approximately 2.05-2.08 $\mathrm{Ma}$.

At Site 552, where discoasters are less abundant than at Site 658 , this event was difficult to define. It is estimated to occur between 36.9 and 38.0 mbsf (approximately 2.00-2.08 Ma). However, this stratigraphic placement is based on the absolute abundance plots, which may be more useful than the percentage relationship in this case. Backman and Shackleton (1983), Backman et al. (1986), and Backman and Pestiaux (1987) only illustrated the abundance of $D$. triradiatus relative to $D$. brouweri and not the absolute abundances of $D$. triradiatus.

Because of the greater abundances of $D$. brouweri and $D$. triradiatus at Site 662 than at Sites 552 and 658 , it was easier to define the base of the D. triradiatus acme, but the $>20 \%$ boundary is not so useful. The first occurrence of $>20 \%$ is at $138.7 \mathrm{mbsf}(2.03 \mathrm{Ma})$, whereas at $133.5 \mathrm{mbsf}(2.07 \mathrm{Ma})$ the relative proportion between these two species is $12 \%$, which is thought to be approximately the base of the acme as a worldwide event. However, at Sites 658 and 662 , this event could probably be refined by counting greater numbers of view fields throughout this interval. Discoaster triradiatus shows a distinct order of reduction in abundance from Sites 659,662 , and 607 to Site 658 . Site 552, however, has much lower abundances than any of the other sites.

Considering that Site 659 was selected as the reference site, it was not expected that the Discoaster abundance variations would be so marked (Fig. 12). The final extinction was quite a sudden event after some high abundances between 1.93 and $1.95 \mathrm{Ma}$. At Site 658, a high abundance event observed at Site 659 is reflected at $1.96 \mathrm{Ma}$. This is the only major event of Discoaster abundance from 2.35 to $1.89 \mathrm{Ma}$ at Site 658. At Site 607 , the greatest abundance of $D$. brouweri occurs between 1.89 and $2.07 \mathrm{Ma}$ (approximately $1.93 \mathrm{Ma}$ ), which may be related to the high abundance events at Sites 658 and 659. A similar pattern is also reflected in D. triradiatus, which is to be expected in view of the evidence implying a strong taxonomic affinity (Backman and Shackleton, 1983).

At Site 662 (Fig. 12), although D. brouweri abundance is lower than at Site 659 , the abundances are still very high in comparison with Sites 607, 552, and 658. At Site 662, there is a major decline in abundance of $D$. brouweri from $2.05 \mathrm{Ma}$ to the extinction at $1.89 \mathrm{Ma}$, and no noticeable abundance peaks occur at 1.95-1.96 Ma, although there is a small core gap close to this interval. Thus, this event may possibly be missing, or it may be a relatively local phenomenon affecting Sites 658, 659 , and, to a lesser degree, 607.

Site 607 shows a much greater abundance of $D$. brouweri than Site 658 after $2.4 \mathrm{Ma}$ and a slightly higher overall abundance prior to this age with a distinct trend toward abundance reduction, although there are a number of distinct peaks in the record of Site 658 at which abundance is higher than at Site 607. Many of the major abundance peaks at Site 662 appear to coincide with those at Site 659 (e.g., at approximately $2.33,2.22$, and $2.18 \mathrm{Ma}$ ). An abundance peak at roughly $2.74 \mathrm{Ma}$ appears to occur at all four sites. No cross-correlation is attempted with Site 552 for any of the species since the abundances are so low (Fig. 13).

\section{Discoaster pentaradiatus and Discoaster surculus}

The abundance of these two species has been compared in different cores and ocean basins by Backman and Shackleton (1983), Backman et al. (1986), and Backman and Pestiaux (1987) and the extinctions are estimated to occur at 2.35-2.45 Ma. It is widely agreed that $D$. surculus disappeared slightly earlier than $D$. pentaradiatus, which is true of the five sites analyzed (Figs. 14 and 15 ).

At Sites $659,658,607$, and 552, a distinct synchronous extinction for $D$. pentaradiatus was recorded at approximately $2.38 \mathrm{Ma}$ (Fig. 14). However, at Site 662, it was less easy to define this extinction due to the heavy reworking despite knowledge of the background level. The age range for the extinction is suggested to occur between the major peak at $2.34 \mathrm{Ma}$ and another peak at $2.41 \mathrm{Ma}$; everything younger than $2.34 \mathrm{Ma}$ is considered to represent reworking. A synchronous extinction for $D$. pentaradiatus at Sites 659 and 658 would be expected in view of their close proximity, but it is interesting that Sites 552 and 607 display the same extinction age in view of the wide range of estimates for the age of this event.

As in the abundance for D. brouweri, Site 659 has higher abundances of $D$. pentaradiatus than Site 658 and, to a lesser extent, Site 662. However, Site 607 showed comparable abundances to Sites 659 and 662 . The two highest latitude sites, 607 and 552, have abundances of $D$. pentaradiatus numerically more significant than $D$. brouweri during this time interval (i.e., prior to $2.38 \mathrm{Ma}$ ).

Sites 659 and 662 clearly show an overall decrease in $D$. pentaradiatus abundance in the period prior to $2.38 \mathrm{Ma}$ that may correspond to a temperature decrease in the North Atlantic. However, Sites 607 and, to a lesser extent, 552, show no clear trend of abundance reduction; indeed, prior to the extinction of $D$. pentaradiatus there is even a slight trend of increasing abundance. It is tempting once again to connect the extinction of $D$. pentaradiatus with the onset of glaciation 


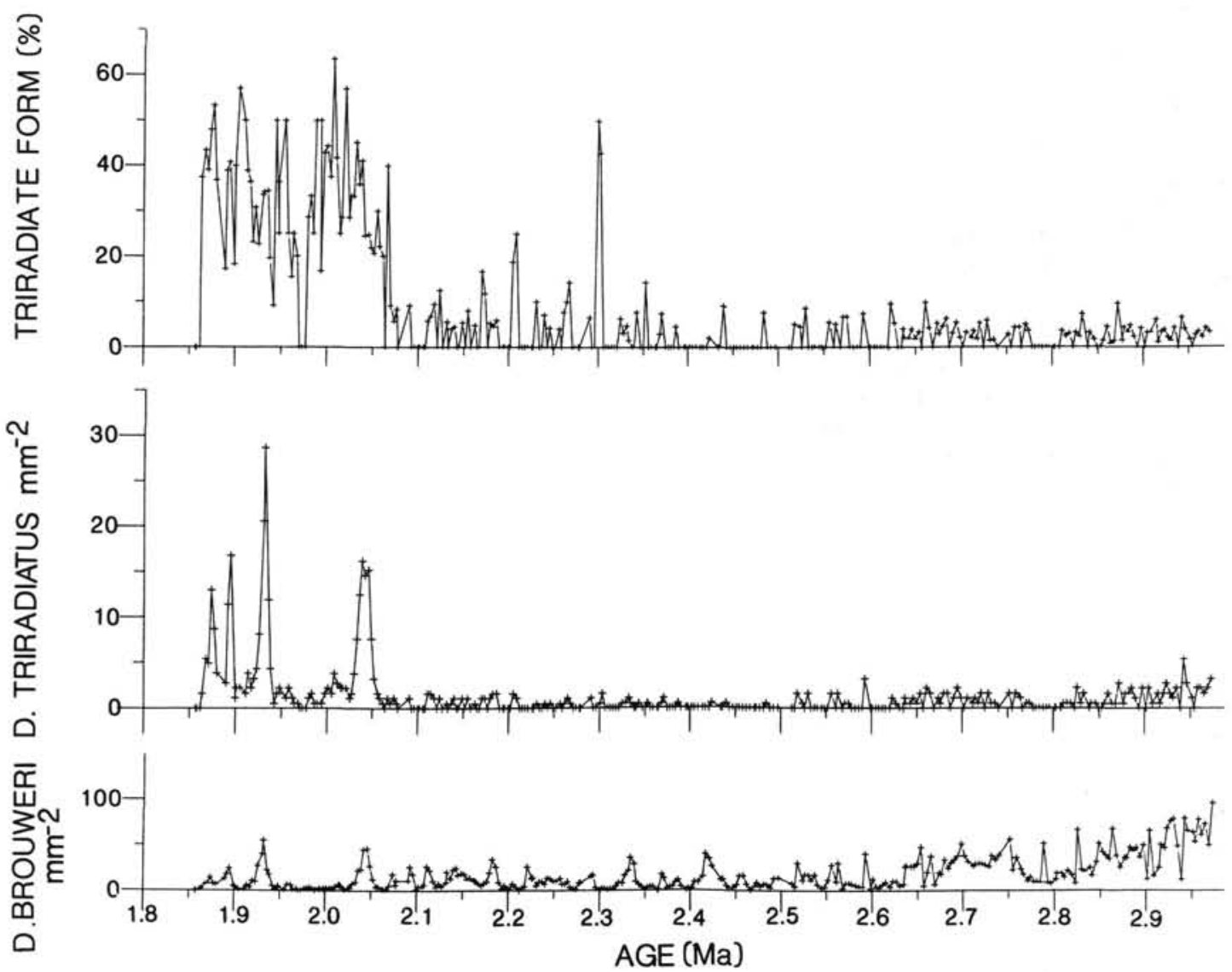

Figure 7. Abundance plots of $D$. brouweri and D. triradiatus at Site 607 . The percentage of the triradiate form is the relative abundance of $D$. triradiatus to the sum of this species with $D$. brouweri.

in the North Atlantic at 2.4 Ma. Many of the abundance peaks seem to correspond among the four sites (e.g., at approximately $2.38,2.71$, and $2.80 \mathrm{Ma}$ ).

Discoaster surculus (Fig. 15) disappeared with a final distinctive peak at $2.39 \mathrm{Ma}$, except at Sites 552 and 607 where the same age is ascertained, although no distinctive peak is identified. The first noticeable feature is that $D$. surculus is more abundant at Site 658 than at Site 662 , although Site 659 displays a still higher abundance. However, at Site $607, D$. surculus shows a greater overall abundance than at all the other sites, which probably relates to its higher latitudinal position. At Site 552, the highest latitudinal site, the abundances are extremely low, but $D$. surculus is the most abundant species (Fig. 13).

Bukry (1978) observed that D. surculus favored the cooler end of the warm-water spectrum among the species of the warm-water genus Discoaster. It can be seen that $D$. surculus is more abundant than $D$. pentaradiatus at Site 658 . Frequently, D. surculus is co-dominant with $D$. brouweri. Since Site 658 is an upwelling site with the associated cooler surface water, it would seem reasonable that $D$. surculus should form a major component of the Discoaster assemblage. At Site 607, $D$. surculus is still slightly lower in overall abundance to $D$. pentaradiatus, but its abundance is comparable to $D$. brouweri. Discoaster brouweri only becomes important when compared with D. surculus and D. pentaradiatus at Site 607 prior to $2.9 \mathrm{Ma}$.

At Site $607, D$. surculus appears to increase in abundance between roughly 2.55 and $2.50 \mathrm{Ma}$, whereas $D$. pentaradiatus continues to increase up until $2.40 \mathrm{Ma}$. At Site 552 (Fig. 13), there is an apparent trend of increasing abundance in $D$. surculus up until $2.50 \mathrm{Ma}$, which is followed by an abrupt decline to the extinction event, though extremely low abundances are involved. Discoaster surculus is presumably less significant at Site 662 , because although this site is supposedly affected by the South Equatorial Current and upwelling to some extent, the reduction in sea-surface temperature is not so marked as in upwelling Site 658 . No noticeable trend of overall decrease in abundance is apparent prior to $2.38 \mathrm{Ma}$, except after $2.54 \mathrm{Ma}$.

There are a number of abundance peaks that appear to correspond among the four sites at approximately 2.54, 2.60, and $2.70 \mathrm{Ma}$. At all five sites, $D$. pentaradiatus and $D$. surculus frequently exhibit an inverse abundance relationship (Backman and Shackleton, 1983). This may provide a potential tool for determining subtle temperature or productivity changes, if we assume that these two species had different ranges of ecological tolerance.

\section{Discoaster asymmetricus and Discoaster tamalis}

The abundance of these two species co-varies, as shown in the almost identical abundance plots at each site (Figs. 16 and 17). This phenomenon has been demonstrated by Backman and Shackleton (1983), Backman et al. (1986), and Backman and Pestiaux (1987) and seems to suggest strong taxonomic affinity. Site 659 shows greater abundances than Site 658 and Site 662 .

Unexpectedly, the abundances of $D$. asymmetricus and $D$. tamalis at Site 607 were higher than at Site 662. At Site 552, the northernmost site, there is a further increase in abundance 

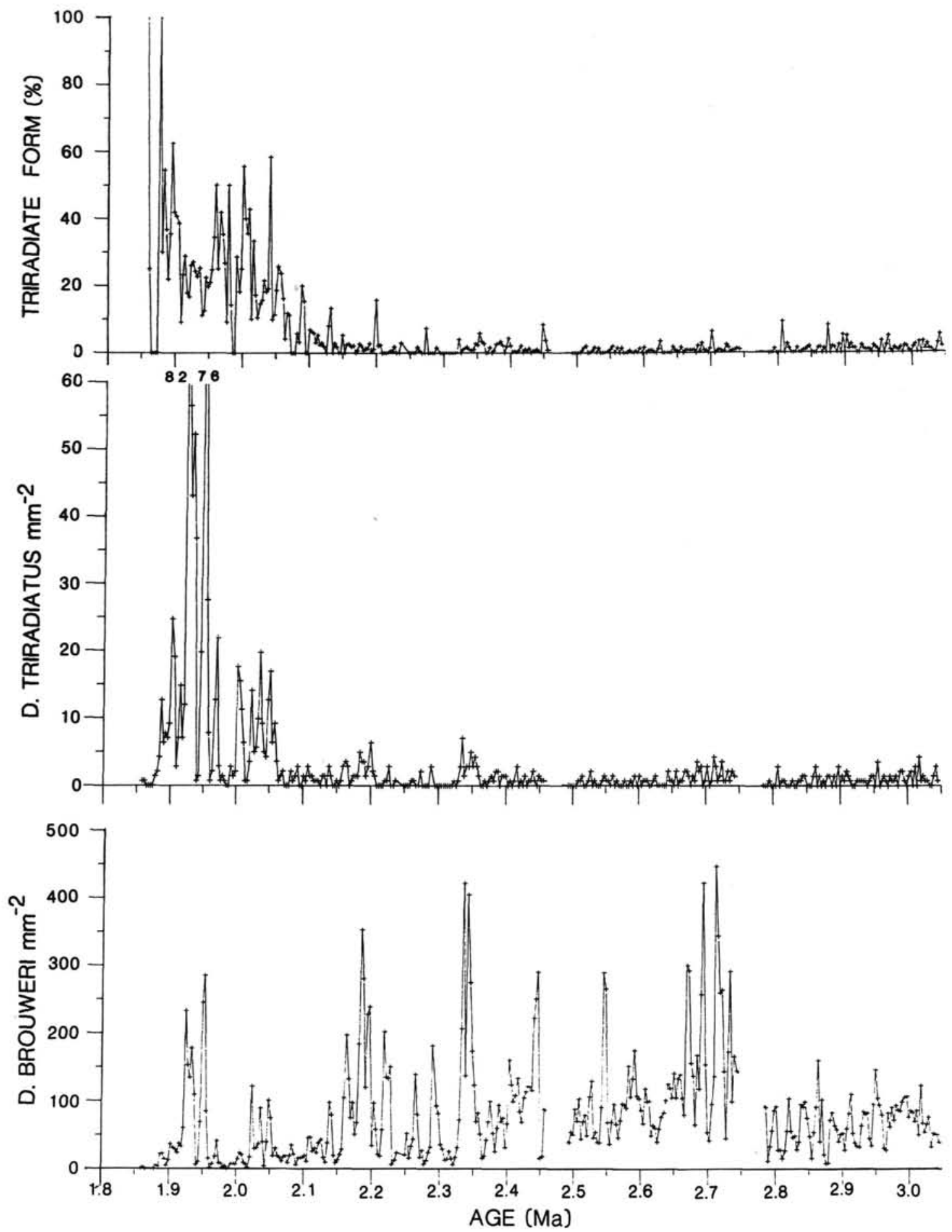

Figure 8. Abundance plots of D. brouweri and D. triradiatus at Site 659.

relative to $D$. brouweri, even though the abundances are extremely low. There may exist a relationship between latitude and the production of $D$. tamalis and $D$. asymmetricus. Upwelling at Sites 658 and 662 may even suppress the production of these two species.

At Site 659 , the synchronous extinction of $D$. tamalis at $2.65 \mathrm{Ma}$ was selected at $79.4 \mathrm{mbsf}$. Arguably, it may even occur a little higher up in the section, but up until this point $D$. tamalis (and D. asymmetricus) had been present continu- ously, even if in low abundances. Discoaster tamalis above this level is considered reworked. At Site 662, the extinction age interpolates to approximately $2.65 \mathrm{Ma}$. Due to the very low abundances of these two species at Site 658 , it was impossible to assess a true extinction level.

At Site 607 , the extinction event is partially concealed by reworking, as shown by the association of $D$. tamalis with Reticulofenestra pseudoumbilica. However, the abundance peaks are discontinuous and the true extinction is observed at 

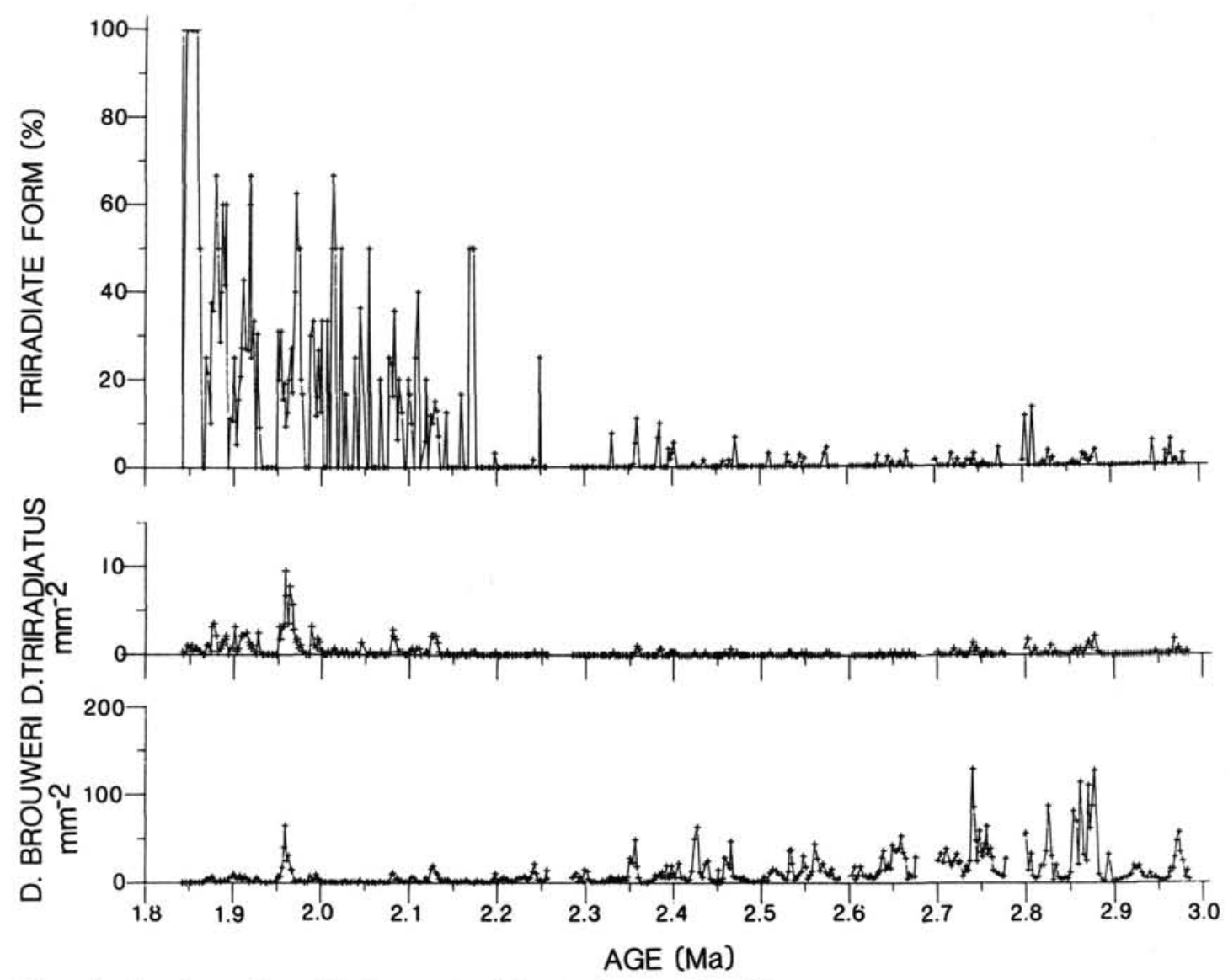

Figure 9. Abundance plots of D. brouweri and D. triradiatus at Site 658.

approximately $2.65 \mathrm{Ma}$, since a continuous presence is recorded prior to this age. This event is not easy to define at Site 552 because it is difficult to distinguish between very low abundances and possible reworking combined with low sedimentation rates. Sites 659,662 , and 607 indicate a clear reduction in abundance through the time interval for both these species up until the extinction of D. tamalis at $2.65 \mathrm{Ma}$.

Discoaster asymmetricus shows an abundance reduction at approximately $2.65 \mathrm{Ma}$, but it continues to occur in low abundances. In such low abundances, it is virtually impossible to attach a reliable age to its extinction. This low abundance phenomenon after $2.65 \mathrm{Ma}$ is observed at all five sites and, thus, is not simply reworking (Backman and Shackleton, 1983). However, at Site 607, it is difficult to distinguish between the presence of $D$. asymmetricus in low abundances and reworking after $2.65 \mathrm{Ma}$, because it is associated with reworked $D$. tamalis. The extinction may even be as young as $2.2 \mathrm{Ma}$, so this is not a useful datum. Another interesting feature is that $D$. tamalis and $D$. asymmetricus mimic the abundance of $D$. brouweri at the five sites. This may indicate taxonomic affinity among these three species. Since D. tamalis and $D$. asymmetricus are numerically insignificant in this interval, except at high latitudes, it would seem more sensible to cross-correlate sites using abundance peaks of $D$. brouweri.

\section{Total Abundance}

Interesting differences are to be noted below $2.35 \mathrm{Ma}$ when one begins to move into the range of other species beside $D$. brouweri, which is the only species covering the whole time interval. Excluding D. variabilis, which begins to appear in small numbers at the base of our time interval, it is only at 2.65
Ma that all the Discoaster species are present. Of the other species, $D$. pentaradiatus and $D$. surculus are numerically most significant.

An immediately noticeable difference among the five sites (Fig. 18) is the higher overall abundance of discoasters at Sites 659 and 662 than at Sites 552, 607, and 658. At Sites 607 and 552 , the effect of cooler surface-water temperatures in association with higher latitudes is probably one important factor; likewise, at Site 658 , its association with upwelling. Shackleton et al. (1984) have shown that the onset of Northern Hemisphere glaciation was a well-defined event at about 2.4 $\mathrm{Ma}$, and it may correlate with the sudden abundance reduction of discoasters at $2.4 \mathrm{Ma}$ at Site 607 and the following $50 \mathrm{k} . \mathrm{y}$. at Site 658. At the latter site, this may perhaps indicate an intensification of upwelling, which may have been less intense before. Even at Site 552, where the abundances are extremely low, an abrupt drop in abundance after $2.4 \mathrm{Ma}$ can be seen (Fig. 13).

At Site 662, discoasters are still reasonably abundant, but the effects of the South Equatorial Current appear to reduce their overall numbers. It is very clear that short-term variations are imprinted on the Discoaster record, but the longterm trend of abundance reduction is apparent, which is possibly linked to the initiation of glaciation in the North Atlantic at $2.4 \mathrm{Ma}$.

To account for the dilution effect by high sedimentation rates, the observed abundances should be multiplied by the sedimentation rates to give a figure more closely proportional to accumulation rates for each species. Sites 607,659 , and 662 would still be roughly comparable as shown, and Site 658 would be increased by a factor of only 2 or 3 relative to these 


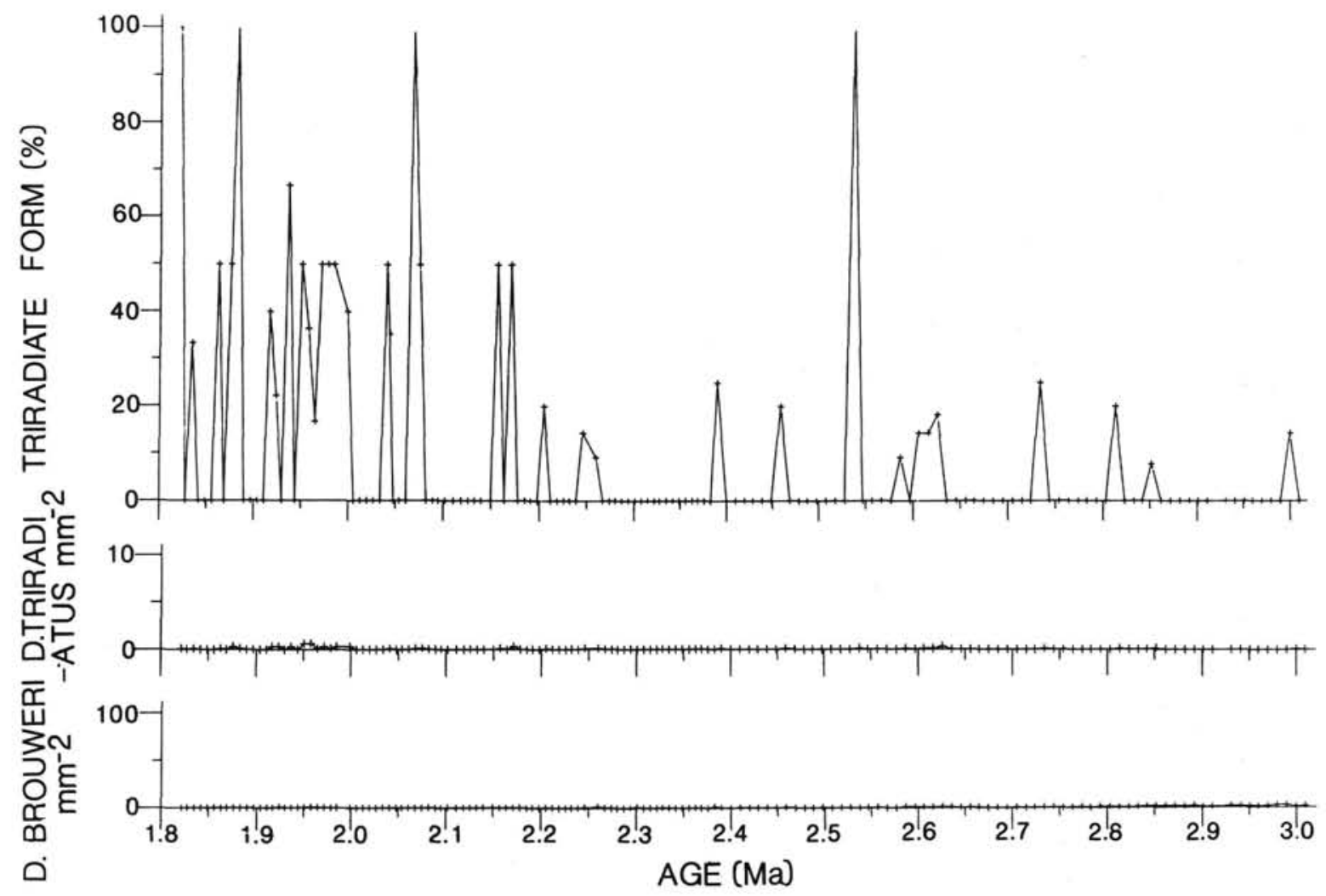

Figure 10. Abundance plots of D. brouweri and D. triradiatus at Site 552.

sites, still showing much lower abundances. Values for Site 552 , however, would be reduced further by roughly a factor of 3 to show even lower abundances.

\section{SPECTRAL ANALYSIS}

Numerous studies have shown that the late Cenozoic paleoclimate varied in response to orbital forcing (e.g., Hays et al., 1976; Pisias and Leinen, 1984; Pestiaux and Berger, 1984). Similarly, since many groups of nannoplankton are restricted to specific temperature ranges (e.g., McIntyre, 1967; Okada and Honjo, 1973; Okada and McIntyre, 1979), it would be expected that their abundances would respond, for example, to changes in sea-surface temperature resulting from orbital forcing. Backman et al. (1986) and Backman and Pestiaux (1987) have already demonstrated this at DSDP Site 606 and Hole 552A.

At Site 606, variance at the frequency of all three orbital elements were obtained, dominated by the $400-\mathrm{k}$.y. periodicity. At DSDP Hole 552A, only the eccentricity and obliquity periodicities were present, of which obliquity was dominant; at this site precessional periodicities may have been undetectable due to the low sedimentation rate, resulting in a temporally coarse sampling interval.

In this study, spectral analysis is based on linear interpolation between the biostratigraphic and magnetostratigraphic control points selected for the age models (Table 3 ). The data sets have been divided into two time intervals: from 1.88 to $2.39 \mathrm{Ma}$ and from 2.39 to $3.00 \mathrm{Ma}$ (Fig. 19). At approximately $2.39 \mathrm{Ma}$, several important events occur, including sudden cooling in the North Atlantic, changes in the sedimentation rate, total Discoaster abundance reduction, the extinction of $D$. surculus, and the near extinction of $D$. pentaradiatus.

For the purposes of this analysis, the sum of all the Discoaster species was investigated in order to reduce the effect of the idiosyncracies of particular species. There is frequently an order-of-magnitude change in Discoaster abundances that is associated with regularly spaced abundance peaks, which indicates that there is a large signal available for spectral analysis.

During the time interval from 1.88 to $2.39 \mathrm{Ma}, D$. brouweri is effectively the only species present, except between 1.89 and 2.07 when D. triradiatus had its acme. At Sites 662, 552 (precession very weak), and 607, concentrations of variance around the frequencies of the orbital elements of eccentricity (100 k.y.), obliquity (41 k.y.), and precession (21 k.y.) are distinguished. At Site 658 , only a possible eccentricity signal is noticeable in this time interval, but this may be due to the very low abundances. The obliquity periodicity occurs at Site 659 , but it is much less defined than the eccentricity and precessional periodicities.

Between 2.39 and $3.00 \mathrm{Ma}$, when a greater Discoaster assemblage is present, the obliquity periodicity is distinct at all the sites except Site 659 , which is dominated by the precessional periodicities. There is some indication of the influence of eccentricity at all sites, but precession is only clearly indicated at Sites 662,659 , and 607 .

Clearly these results will be significantly modified as we apply more complex age models. Our strategy here was to investigate whether in the presence of marked aperiodic fluctuations in the abundance of individual species and a long-term decline toward extinction in the Discoaster group, it would still be possible to detect the periodicities characteristic of orbital forcing. Our data suggests that it is indeed possible.

After oxygen isotope data becomes available for more of the sites, it will be possible to generate refined time scales for each site and to gain a better estimate of the characteristics of the forced and unforced components of Discoaster variability. 


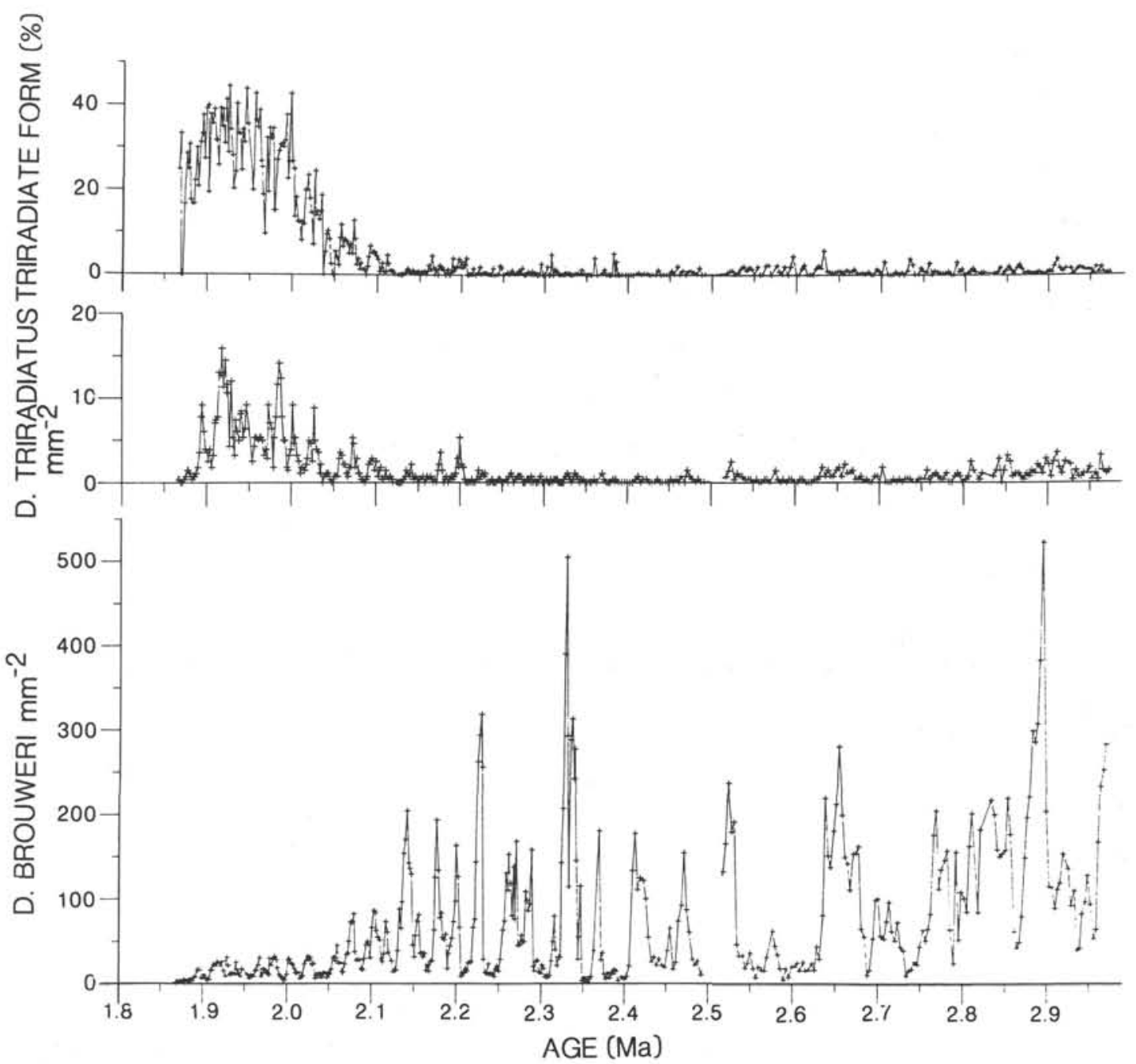

Figure 11. Abundance plots of D. brouweri and D. triradiatus at Site 662.

This will enable us to assess the prospects for using apparent orbital frequencies in Discoaster data to develop an astronomically calibrated time scale in the interval prior to $2.4 \mathrm{Ma}$, when isotopic fluctuations are much reduced.

\section{DISCUSSION}

Orbital forcing has been shown to be imprinted strongly on the Discoaster abundances at these sites, presumably acting through sea-surface temperature variability. Total Discoaster abundances are reduced with increasing latitude and upward toward their extinction. Is this caused only by a reduction in temperature with latitude and through time?

Previous studies have suggested that Discoaster abundances are responding only to temperature changes. However, results from this work, especially from the tropical sites, that show large abundance variations clearly suggest that other factors must be important. One possible factor is productivity pressure. In view of the suppressed abundances at the upwelling site (Site 658), it seems tenable to conclude that regions of high productivity are associated with reduced Discoaster abundance (supported by our unpublished observations at Site 677 in the Panama Basin). The Discoaster assemblage appears to tolerate a wide temperature range up to $41^{\circ} \mathrm{N}$; but between this latitude and $56^{\circ} \mathrm{N}$, a threshold is reached beyond which the abundances are suddenly reduced.
Discoaster brouweri was certainly reduced in abundance with latitude. Prior to $2.38 \mathrm{Ma}, D$. surculus and D. pentaradiatus are important components of the Discoaster assemblage. Rapid cooling in the North Atlantic at 2.4 Ma (Shackleton et al., 1984) seems to correlate (coincidentally?) with the extinction of these two species at 2.39 and $2.38 \mathrm{Ma}$, respectively. Discoaster surculus increased significantly relative to $D$. brouweri as a function of increasing latitude and upwelling conditions. Its distribution through time, however, shows no clear trend of abundance reduction, and it seems to signal a reduction in sea-surface temperatures less than any of the other species. It seems probable that its distribution through time and space was in response to a productivity signal. Nevertheless, latitude does limit its distribution and its abundance is reduced above $41^{\circ} \mathrm{N}$.

As far north as $18^{\circ} \mathrm{N}, D$. pentaradiatus shows a clear trend of reduction through time, but north of this latitude no such trend is apparent. It maintained a fairly constant abundance up to $41^{\circ} \mathrm{N}$, excluding upwelling Site 658 ; it was less abundant at higher latitudes.

These two species clearly possess an inverse abundance relationship, so what could have been their differences in ecological requirements? Discoaster surculus may have favored cooler, more nutrient-rich waters, and $D$. pentaradiatus may have preferred slightly warmer, less nutrient-rich waters. Assuming ecological tolerances did not shift greatly through 

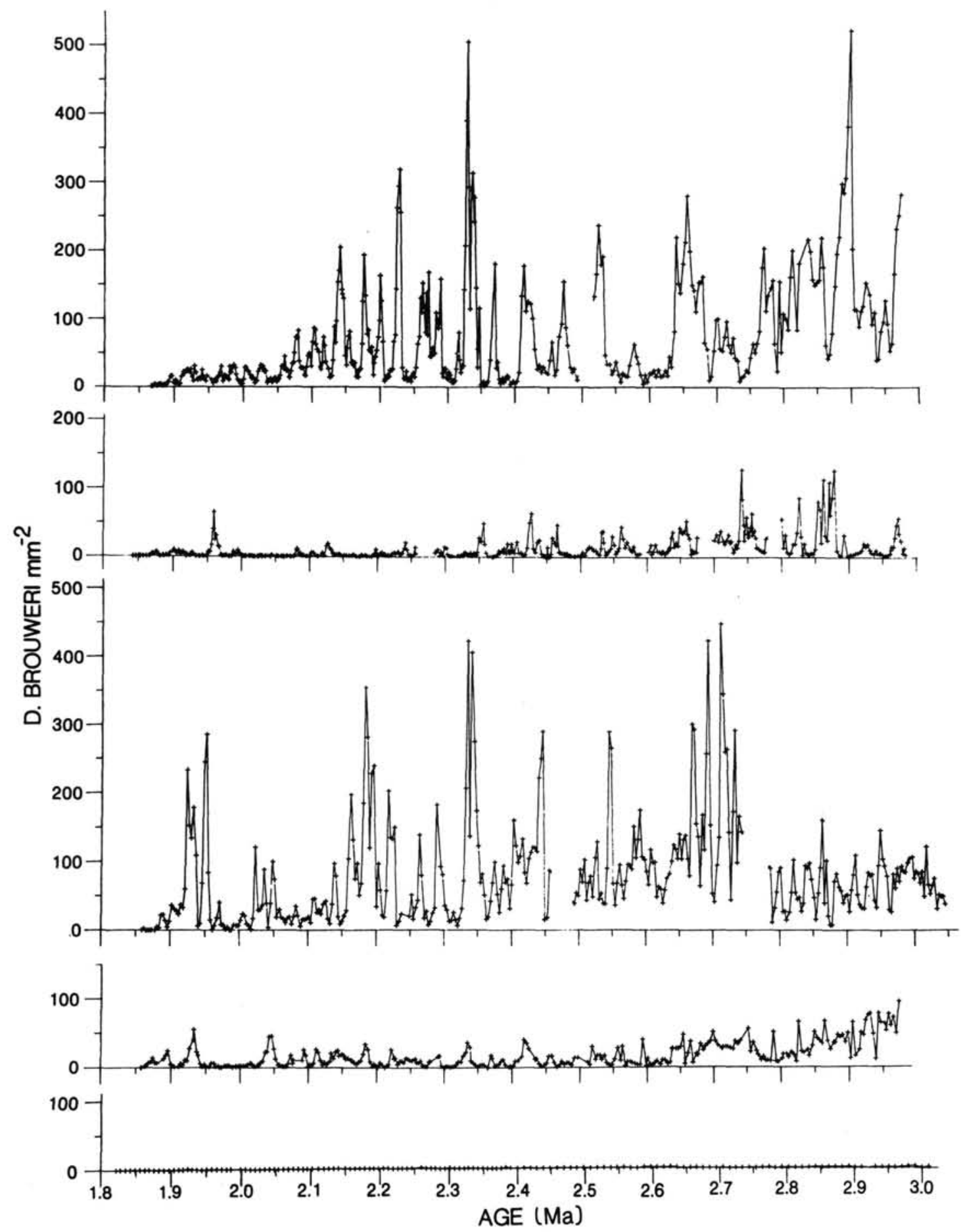

Figure 12. Abundance plots of D. brouweri at Sites 552, 607,659, 658, and 662. Gaps in plots are core breaks.

time, D. brouweri may have favored even warmer, less nutrientrich waters.

The covariation of $D$. brouweri with $D$. triradiatus, and $D$. brouweri with $D$. asymmetricus and $D$. tamalis seems to suggest taxonomic affinity, but this creates some interesting questions. A single species of phytoplankton may have produced different types of discs at different times, with a trend toward reducing calcite (e.g., D. tamalis to D. triradiatus). However, this species must have consistently produced the six-rayed $D$. brouweri through the time interval investigated (1.89-3.00 Ma).

Discoaster tamalis and D. asymmetricus were also produced in virtually identical abundances, but only one of these disappeared globally at $2.65 \mathrm{Ma} ; D$. asymmetricus continued to occur in low abundances as late as $2.2 \mathrm{Ma}$, though the true extinction is indistinct. It may even be that the continuing presence of $D$. asymmetricus is not of any ecological significance, but merely some error in the mechanism for producing 

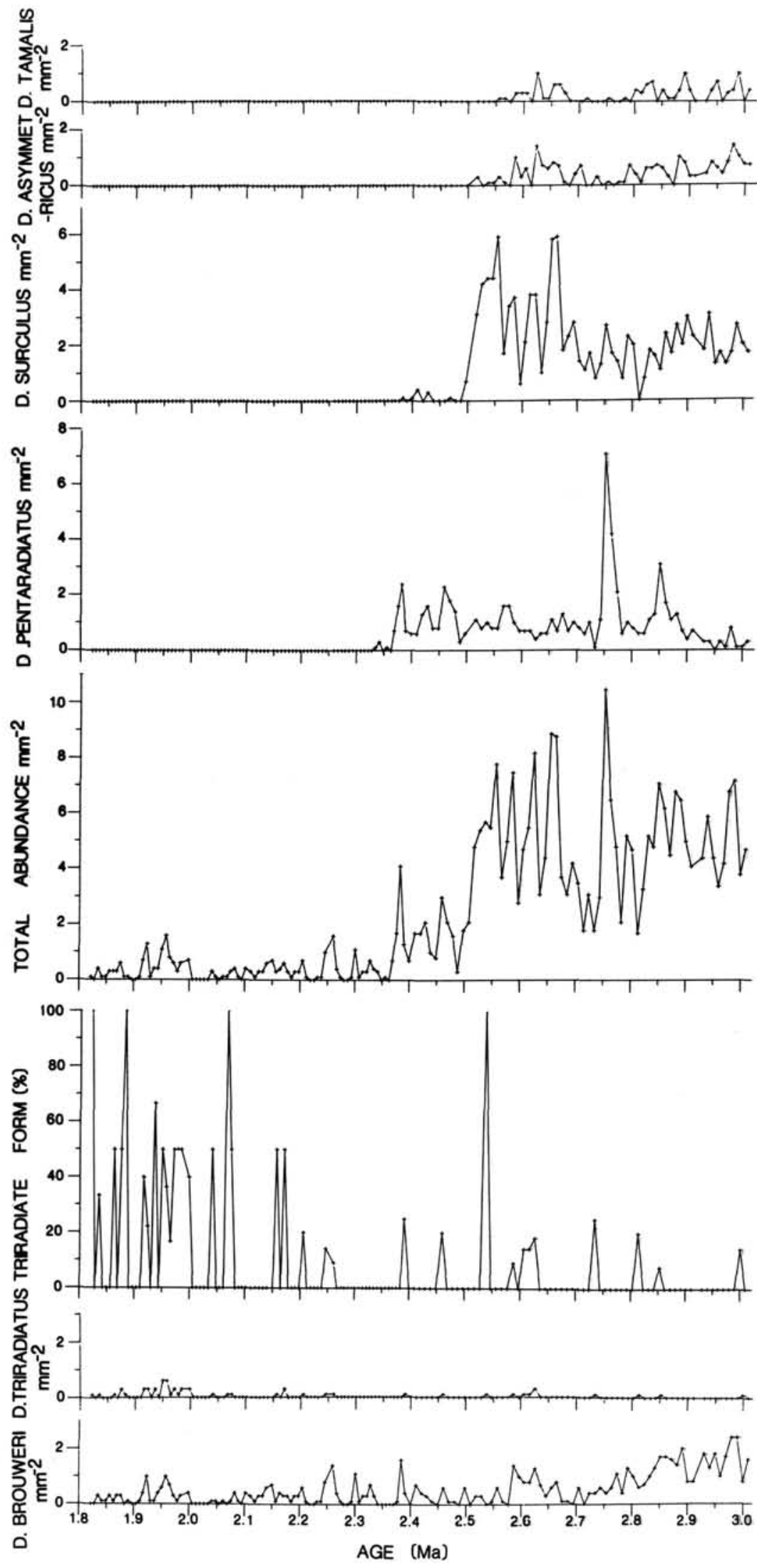

Figure 13. Abundance plots of $D$. brouweri, D. triradiatus, total abundance, $D$. pentaradiatus, D. surculus, D. asymmetricus, and D. tamalis at Site 552. Notice the change in abundance scale. 


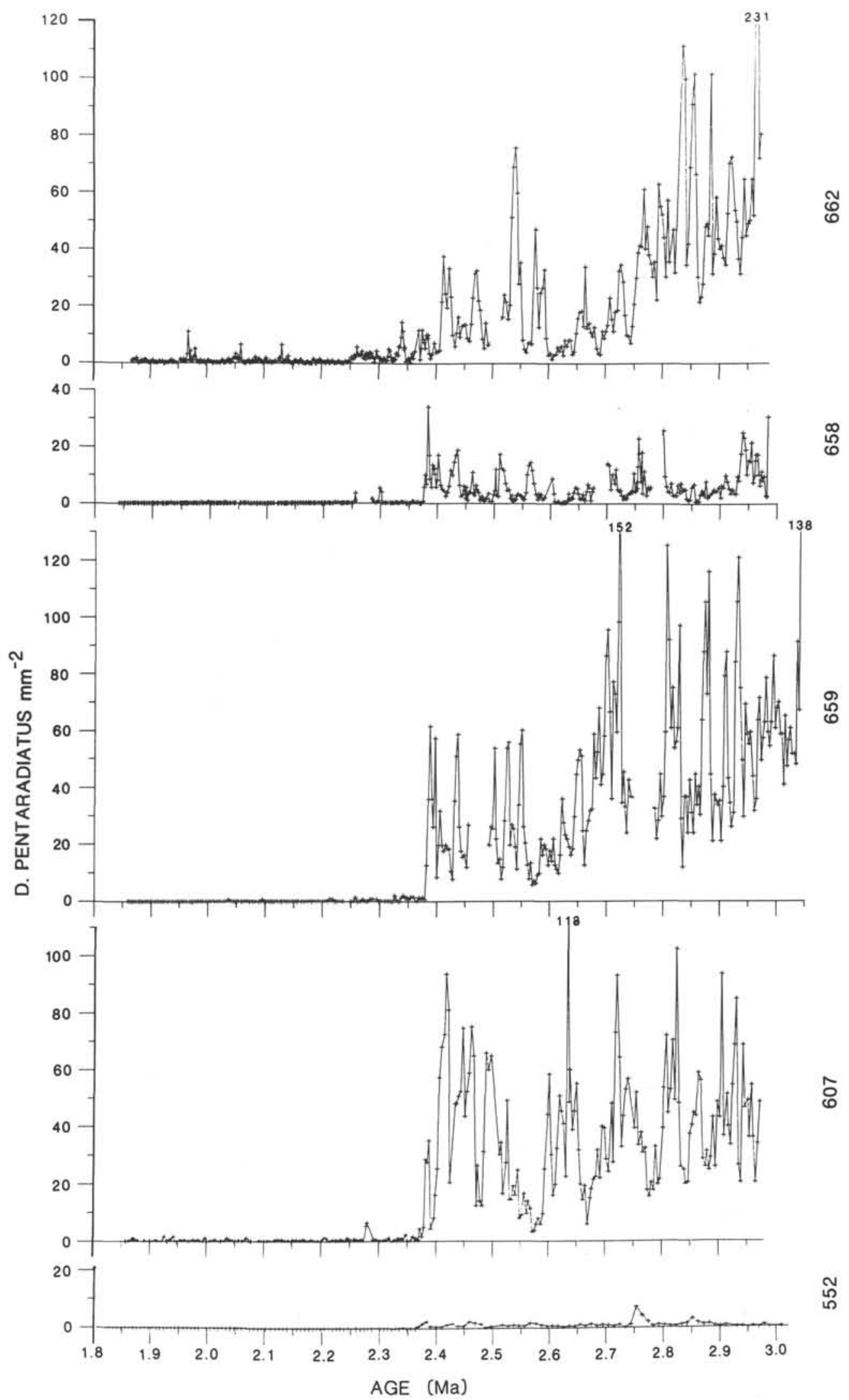

Figure 14. Abundance plots of $D$. pentaradiatus at Sites $552,607,659,658$, and 662 . The abundance scale has been reduced five times in comparison with the abundance plots of $D$. brouweri. 


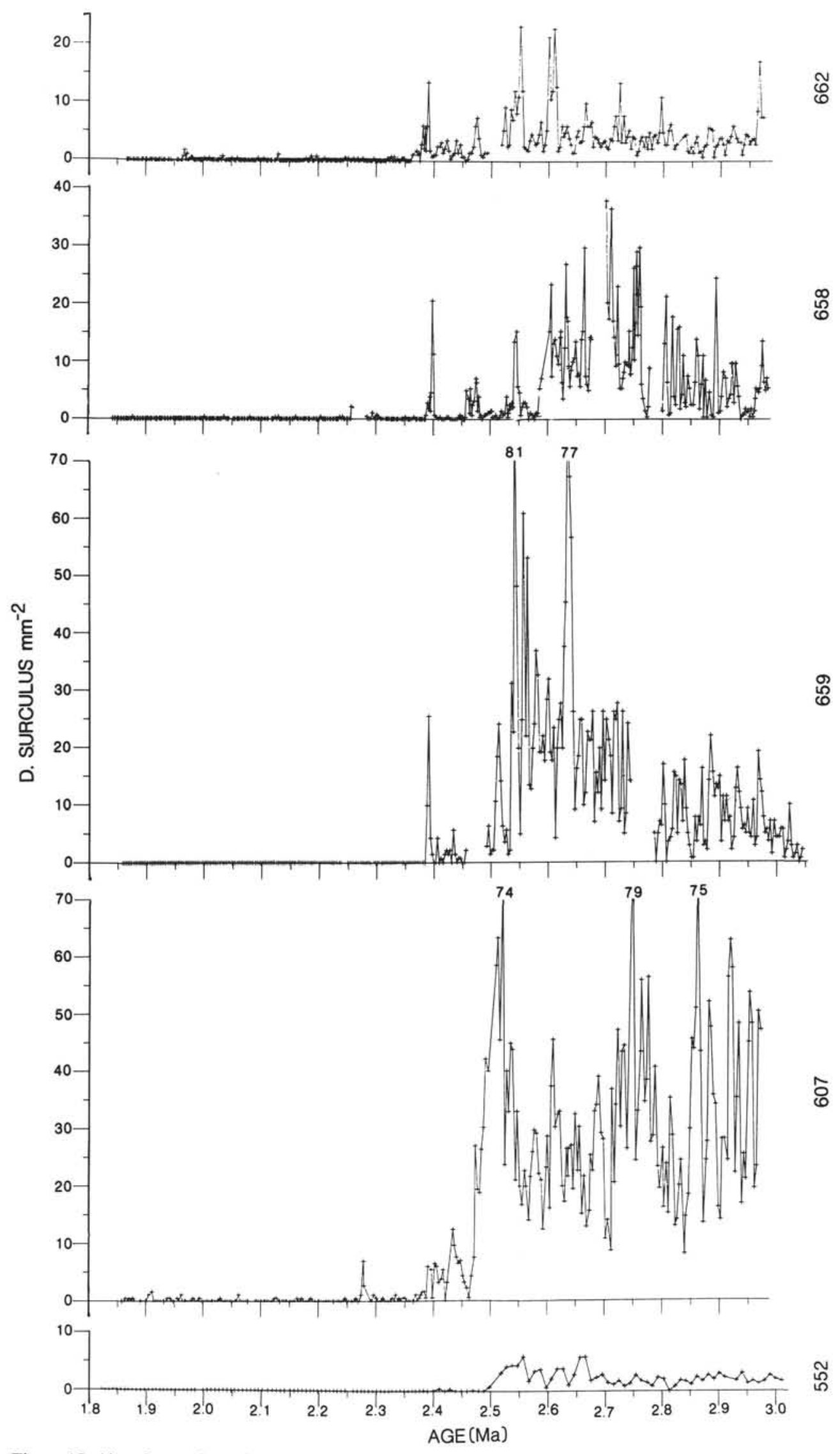

Figure 15. Abundance plots of D. surculus at Sites 552, 607,659, 658, and 662. The abundance scale has been reduced twice in comparison with the abundance plots of $D$. pentaradiatus. 


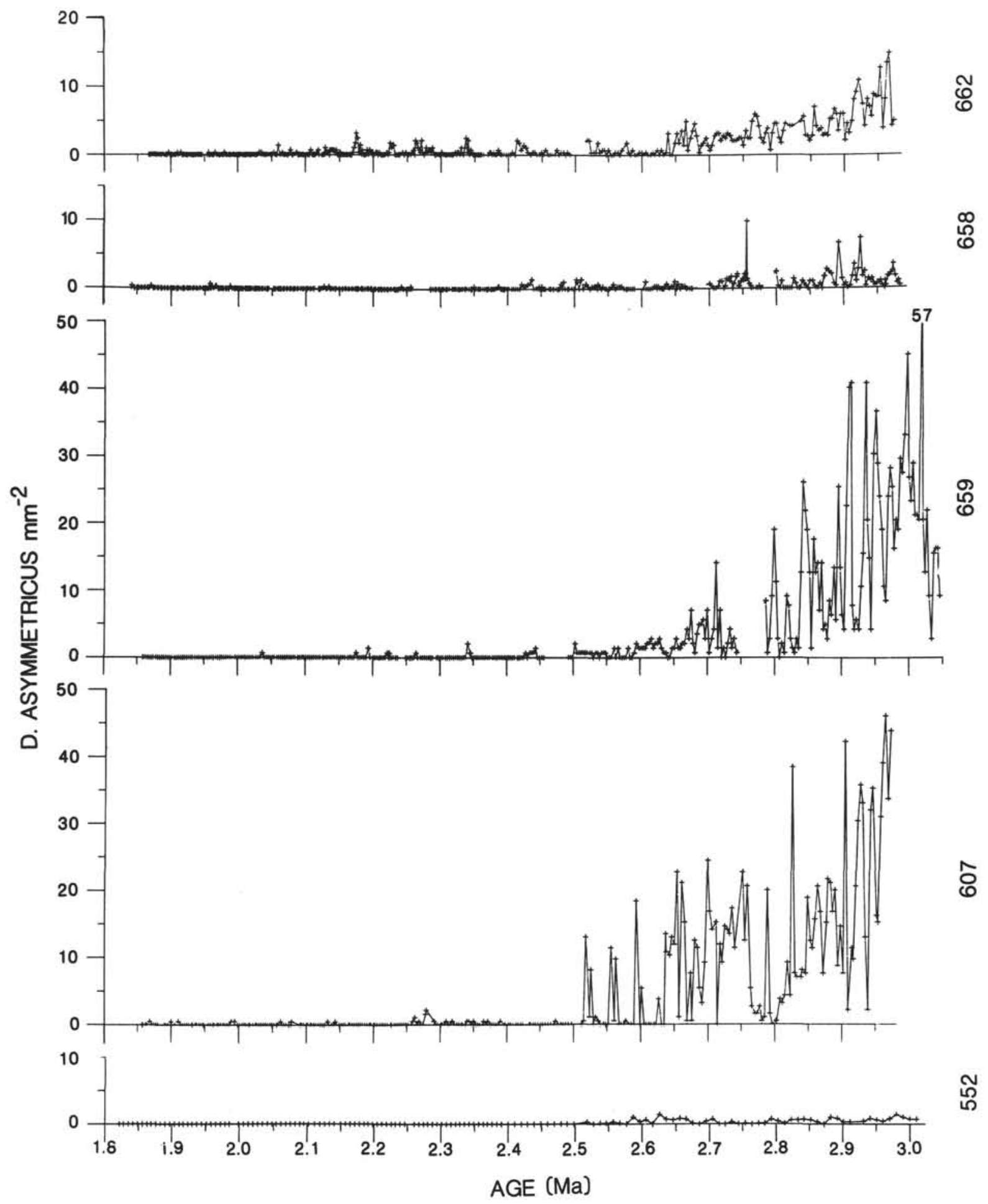

Figure 16. Abundance plots of $D$. asymmetricus at Sites $552,607,659,658$, and 662 . The abundance scale is the same as $D$. surculus and D. tamalis.

the six-armed $D$. brouweri. Discoaster asymmetricus and $D$. tamalis show a distinct trend of reduction in abundance through time up until $2.65 \mathrm{Ma}$, but they actually increase in abundance relative to $D$. brouweri with increasing latitude. A possible solution is that the unknown phytoplankton species produced D. asymmetricus and D. tamalis in equal amounts in its structure, but more commonly with lower temperatures and higher latitude.

Since it is not known what the Discoaster organism looked like, it is difficult to speculate about the function of these different types of discs. However, some species of coccolithophorids today are known to produce different types of cocco- 


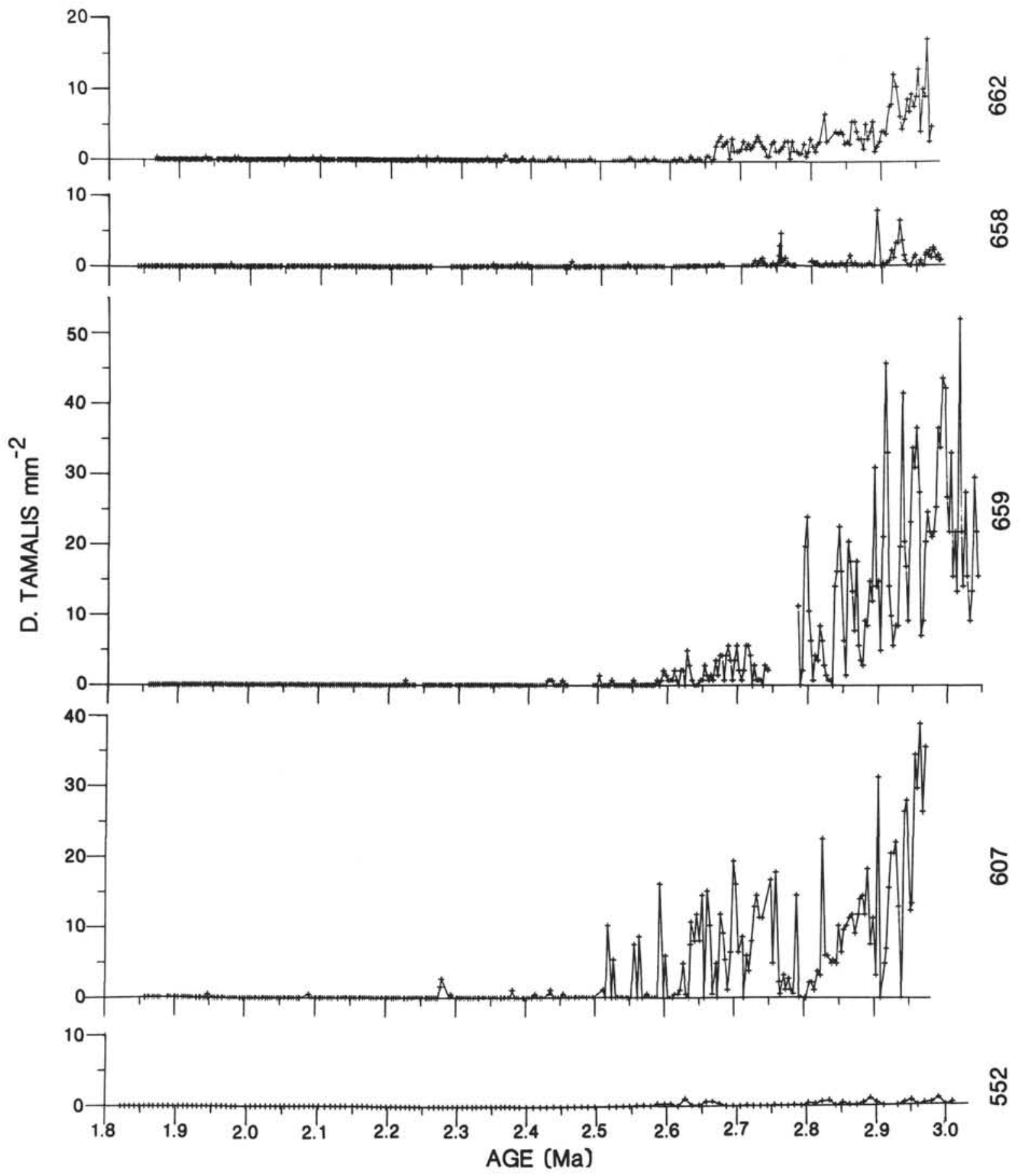

Figure 17. Abundance plots of D. tamalis at Sites 552,607,659,658, and 662 . The abundance scale is the same as D. surculus and D. asymmetricus.

liths in the same organism at the same time or under different ecological conditions.

\section{SUMMARY}

Total Discoaster abundance is reduced by increasing latitude. Prior to $2.38 \mathrm{Ma}$, the abundance of $D$. brouweri declines more rapidly with increasing latitude than the abundance of such other species as D. pentaradiatus and D. surculus.
Discoaster surculus forms a greater component of the Discoaster assemblage with increasing latitude and in upwelling conditions.

Discoaster asymmetricus and D. tamalis increase with latitude relative to $D$. brouweri, with which they appear to be taxonomically related.

Marked fluctuations in the abundance of discoasters are in the frequency range of earth orbital variations. However, the high variability observed in the tropics cannot be solely related to temperature changes resulting from orbital forcing, 


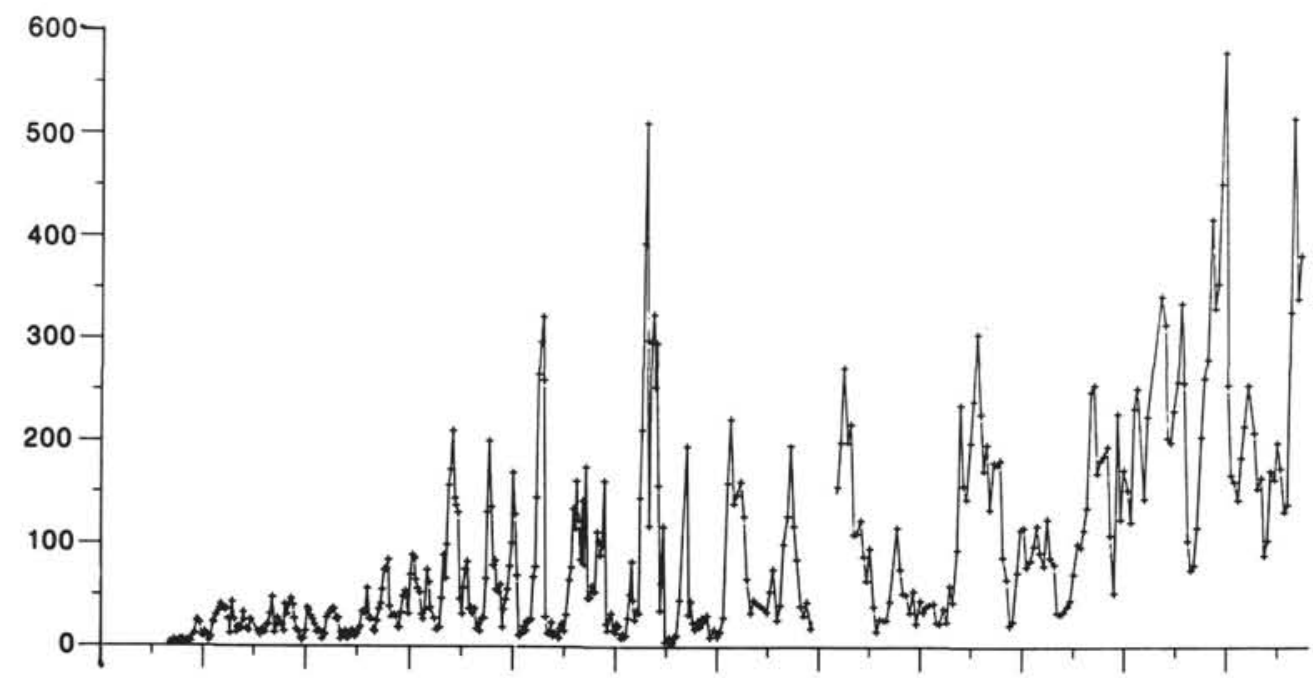

ญ్

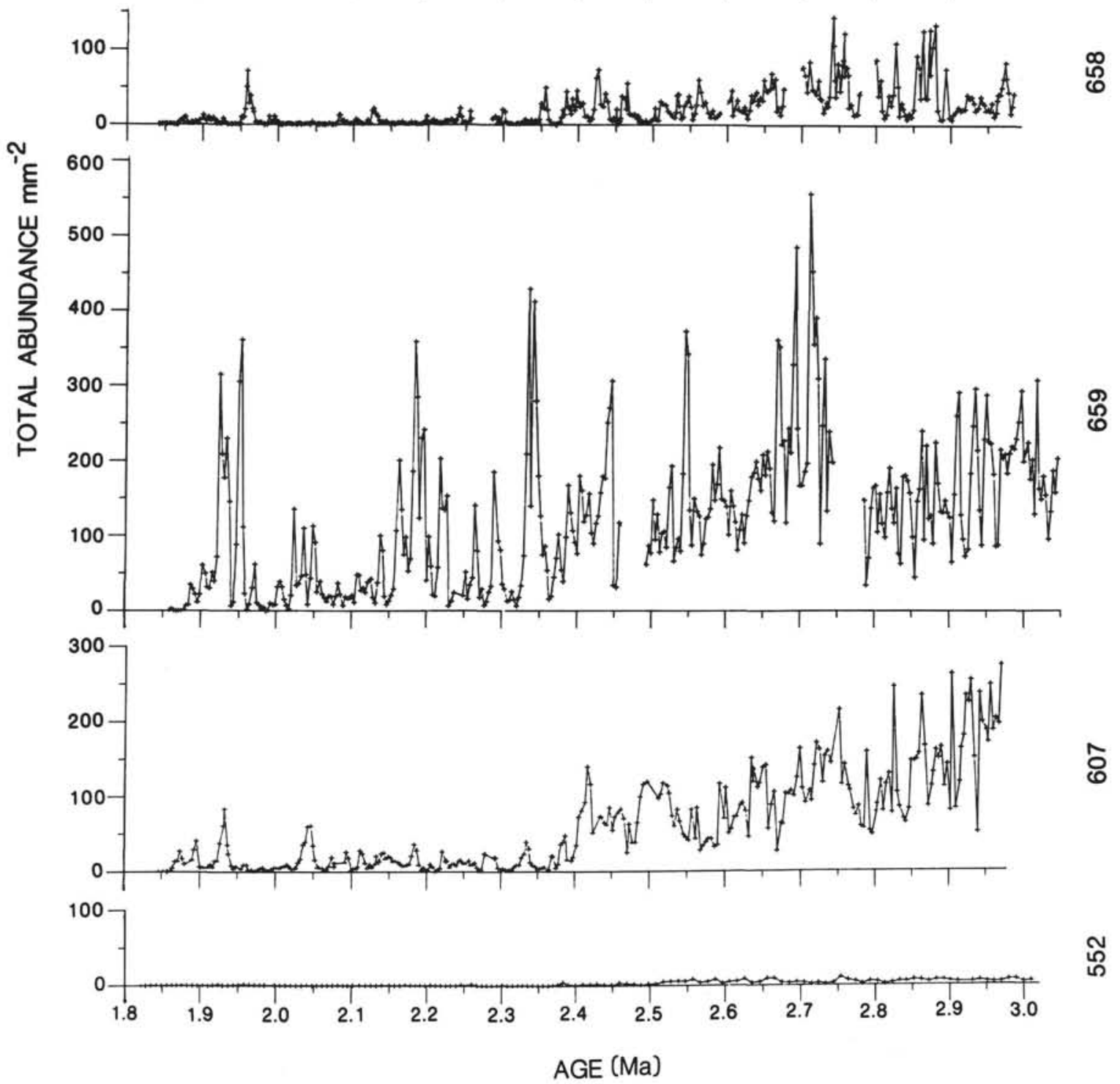

Figure 18. Plots of total Discoaster abundance at Sites 552, 607, 659, 658, and 662. Gaps in plots are core breaks. 
COMPARISON OF UPPER PLIOCENE DISCOASTER ABUNDANCE VARIATIONS
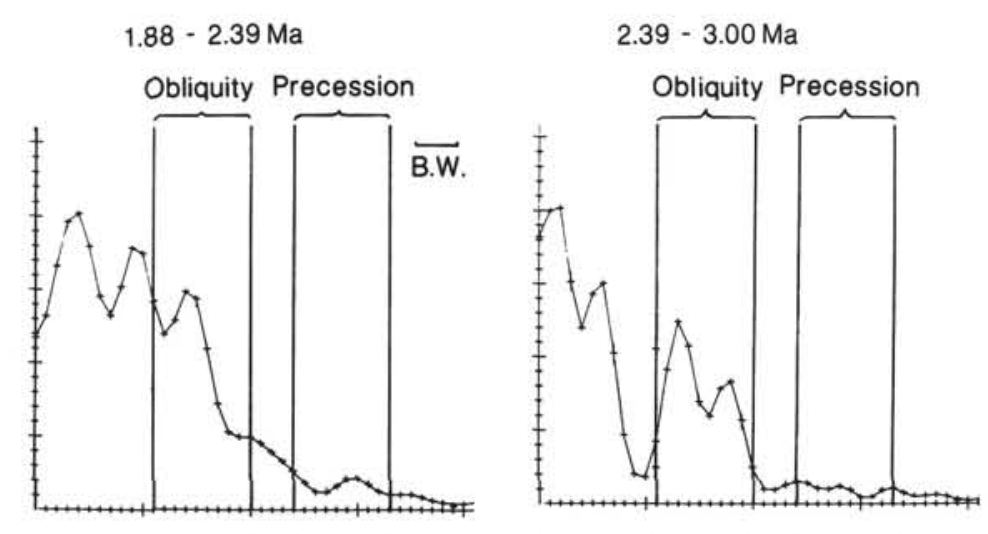

552
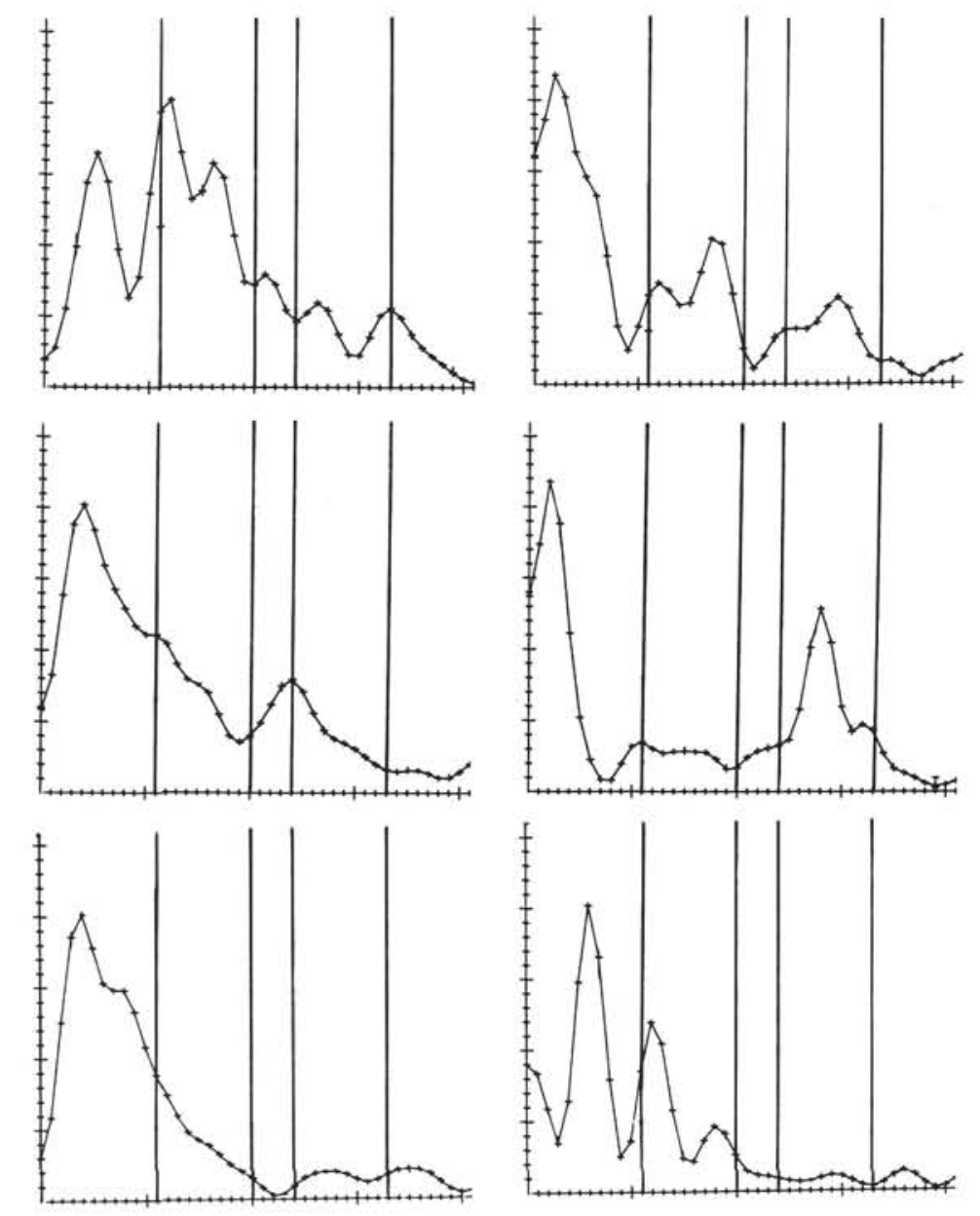

607

659

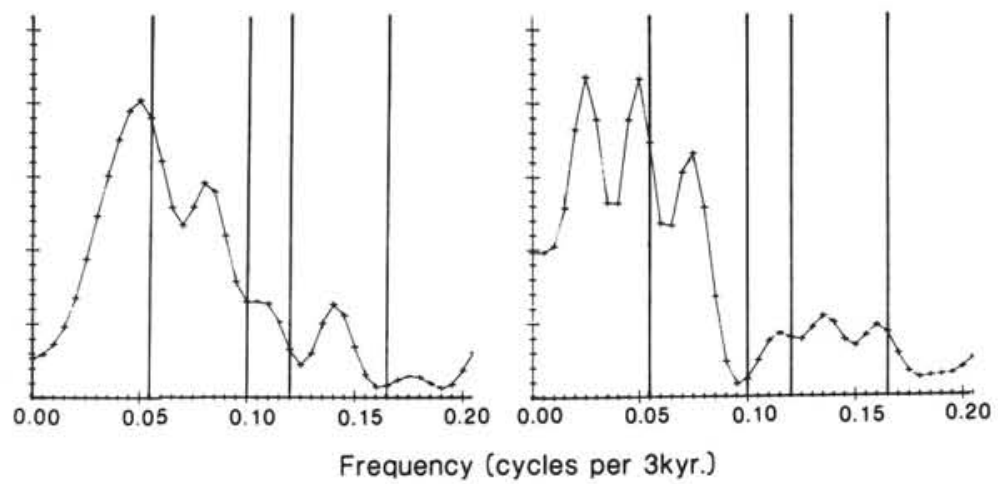

662

Figure 19. Spectral power density estimated on two time intervals of the total Discoaster data set at Sites 552,607,659,658, and 662 . B.W. indicates band width.

139 
but may imply that varying productivity pressure was the primary control.

The extinctions of $D$. surculus and $D$. pentaradiatus as well as the drastic reduction in total Discoaster abundance north of $18^{\circ} \mathrm{N}$ and at upwelling Site 658 seem to correlate with an abrupt drop in sea-surface temperature in the North Atlantic at 2.4 Ma. At sites south of $20^{\circ} \mathrm{N}$, the extinction of D. surculus is characteristically preceded by a distinctive brief peak in abundance.

Many of the distinct Discoaster abundance peaks that are observed can be correlated between sites, an observation that may prove useful in the future in refining stratigraphic correlations.

\section{ACKNOWLEDGMENTS}

We thank the Ocean Drilling Program and the shipboard scientists of ODP Leg 108 and DSDP Legs 81 and 94 who made this study possible. A. Chepstow-Lusty was supported financially by the Natural Environmental Research Council. S. Robinson, J. Erez, and R. M. Corfield provided useful discussions and material assistance. We gratefully acknowledge the very helpful reviews made by Andrew McIntyre, Michael Sarnthein, and William F. Ruddiman.

\section{REFERENCES}

Backman, J., Pestiaux, P., Zimmerman, H., and Hermelin, O., 1986. Palaeoclimatic and palaeoceanographic development in the Pliocene North Atlantic: Discoaster accumulation and coarse fraction data. In Summerhayes, C. P., and Shackleton, N. J., North Atlantic Palaeoceanography. Geol. Soc. Spec. Pap. (London), 21:231-242.

Backman, J., and Shackleton, N. J., 1983. Quantitative biochronology of Pliocene and early Pleistocene calcareous nannofossils from the Atlantic, Indian and Pacific oceans. Mar. Micropaleontol., 8:141-170.

Backman, J., and Pestiaux, P., 1987. Pliocene Discoaster abundance variations, Deep Sea Drilling Project Site 606: biochronology and paleoenvironmental implications. In Ruddiman, W. F., Kidd, R. B., Thomas, E., et al., Init. Repts DSDP, 94, Pt. 2: Washington (U.S. Govt. Printing Office), 903-910.

Bukry, D., 1978. Biostratigraphy of Cenozoic marine sediment by calcareous nannofossils. Micropaleontology, 24:44-60.

Clement, B., and Robinson, F., 1987. The magnetostratigraphy of Leg 94 sediments. In Ruddiman, W. F., Kidd, R. B., Thomas E., et al., Init. Repts. DSDP, 94, Pt. 2: Washington (U.S. Govt. Printing Office), 635-650.

Haq, B. U., and Lohmann, G. P., 1976. Early Cenozoic calcareous nannoplankton biogeography of the Atlantic Ocean. Mar. Micropaleontol., 1:119-194.
Hays, J. D., Imbrie, J., and Shackleton, N. J., 1976. Variations in the earth's orbit: pacemaker of the ice ages. Science, 194:1121-1132.

Lohmann, G. P., and Carlson, J. J., 1981. Oceanographic significance of Pacific late Miocene calcareous nannoplankton. Mar. Micropaleontol., 6:553-579.

McIntyre, A., 1967. Coccoliths as paleoclimatic indicators of Pleistocene glaciation. Science, 158:1314-1317.

Okada, H., and Honjo, S., 1973. The distribution of oceanic coccolithophorids in the Pacific. Deep-Sea Res., 20:355-374.

Okada, H., and McIntyre, A., 1979. Seasonal distribution of modern coccolithophores in the western North Atlantic Ocean. Mar. Biol., $54: 319-328$

Pestiaux, P., and Berger, A., 1984. An optimal approach to the spectral characteristics of deep-sea climate records. In Berger, A., Imbrie, J., Hays, J., Kukla, G., and Saltzman, B. (Eds.), Milankovitch and Climate: Hingham, MA (D. Riedel), 417-446.

Pisias, N. G., and Leinen, M., 1984. Milankovitch forcing of the oceanic system: evidence from the northwest Pacific. In Berger, A., Imbrie, J., Hays, J., Kukla, G., and Saltzman, B. (Eds.), Milankovitch and Climate: Hinghain, MA (D. Riedel), 307-330.

Rio, D., 1982. The fossil distribution of coccolithophore genus $\mathrm{Ge}$ phyrocapsa Kamptner and related Plio-Pleistocene chronostratigraphic problems. In Prell, W. L., Gardner, J. V., et al., Init. Repts. DSDP, 68: Washington (U.S. Govt. Printing Office), 325-343.

Roberts, D. G., Schnitker, D., et al., 1984. Init. Repts. DSDP, 81: Washington (U.S. Govt. Printing Office).

Ruddiman, W. F., Sarnthein, M., et al., 1988. Init. Repts, ODP, 108: Washington (U.S. Govt. Printing Office).

Shackleton, N. J., Backman, J., Zimmerman, H. G., Kent, D. V., Hall, M. A., Roberts, D. G., Schnitker, D., Baldauf, J. G., Desprairies, A., Homrighausen, R., Huddleston, P., Keene, J. B., Kaltenback, A. J., Krumsiek, K. A., Morton, A. C., Murray, J. W., and Westberg-Smith, J., 1984. Oxygen isotope calibration of the onset of ice rafting: history of glaciation in the North Atlantic region. Nature (London), 307:320-323.

Shipboard Scientific Party, 1983. Site 607: background and objectives. In Ruddiman, W. F., Kidd, R. B., Thomas, E., et al., Init. Repts. DSDP, 94, Pt. 1: Washington (U.S. Govt. Printing Office), 75-147.

Takayama, T., 1970. The Pliocene-Pleistocene boundary in the Lamont Core V21-98 and at le Castella, southern Italy. J. Mar. Geol., 6:70-77.

Date of initial receipt: 7 April 1988

Date of acceptance: 12 February 1989

Ms 108B-122 


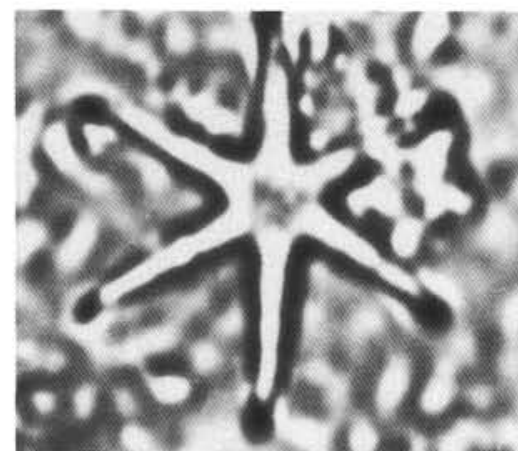

1

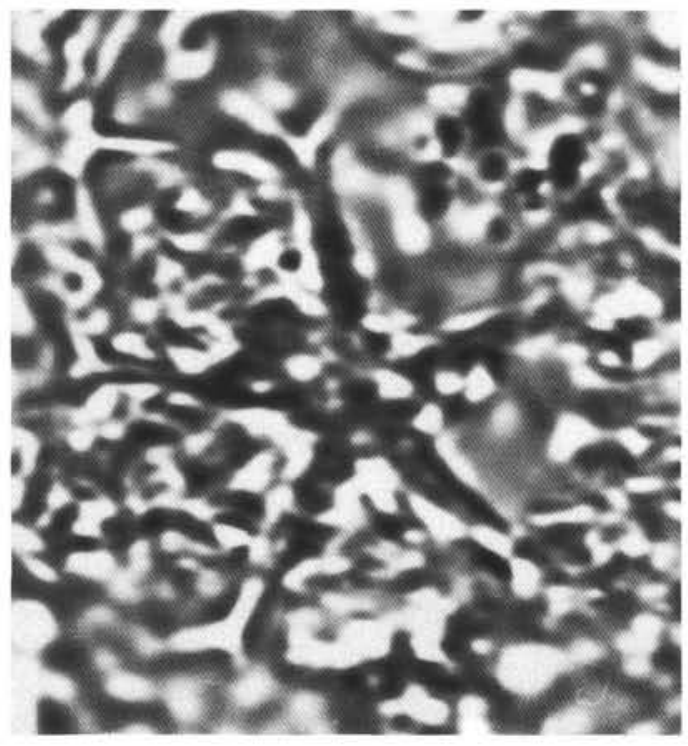

3

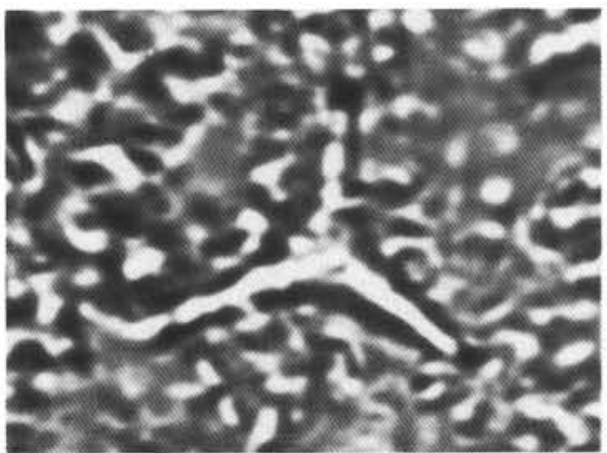

2

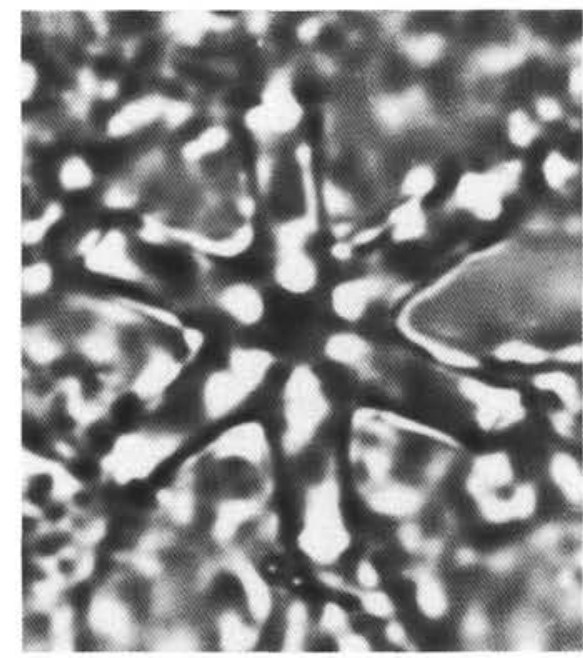

4

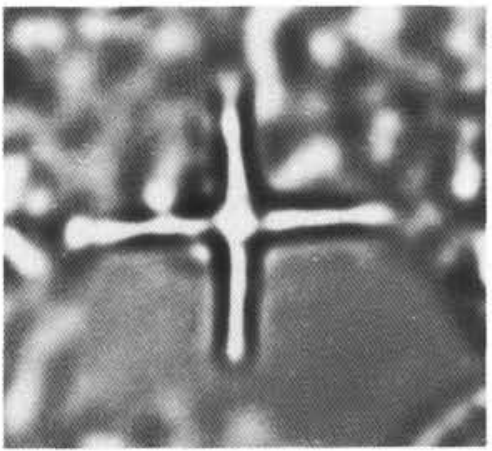

6
5

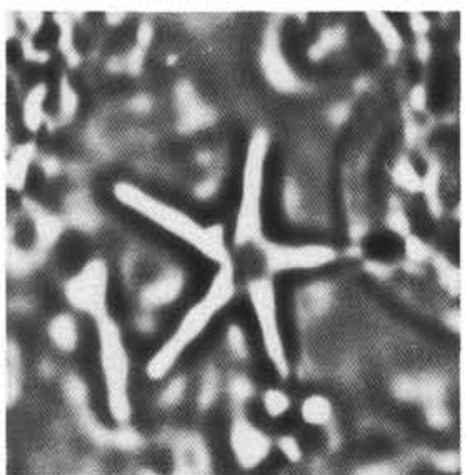

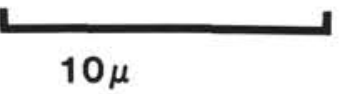

Plate 1. Species of Discoaster. 1. Discoaster brouweri Tan Sin Hok. 2. Discoaster triradiatus Tan Sin Hok. 3. Discoaster pentaradiatus Tan Sin Hok. 4. Discoaster surculus Martini and Bramlette. 5. Discoaster asymmetricus Gartner. 6. Discoaster tamalis Kamptner. 